AIRPHOTO INTERPRETATION OF ENGINEERING SOILS OF INTERSTATE HIGHWAY ROUTE I-65 IN NEWTON, JASPER, WHITE AND TIPPECANOE COUNTIES

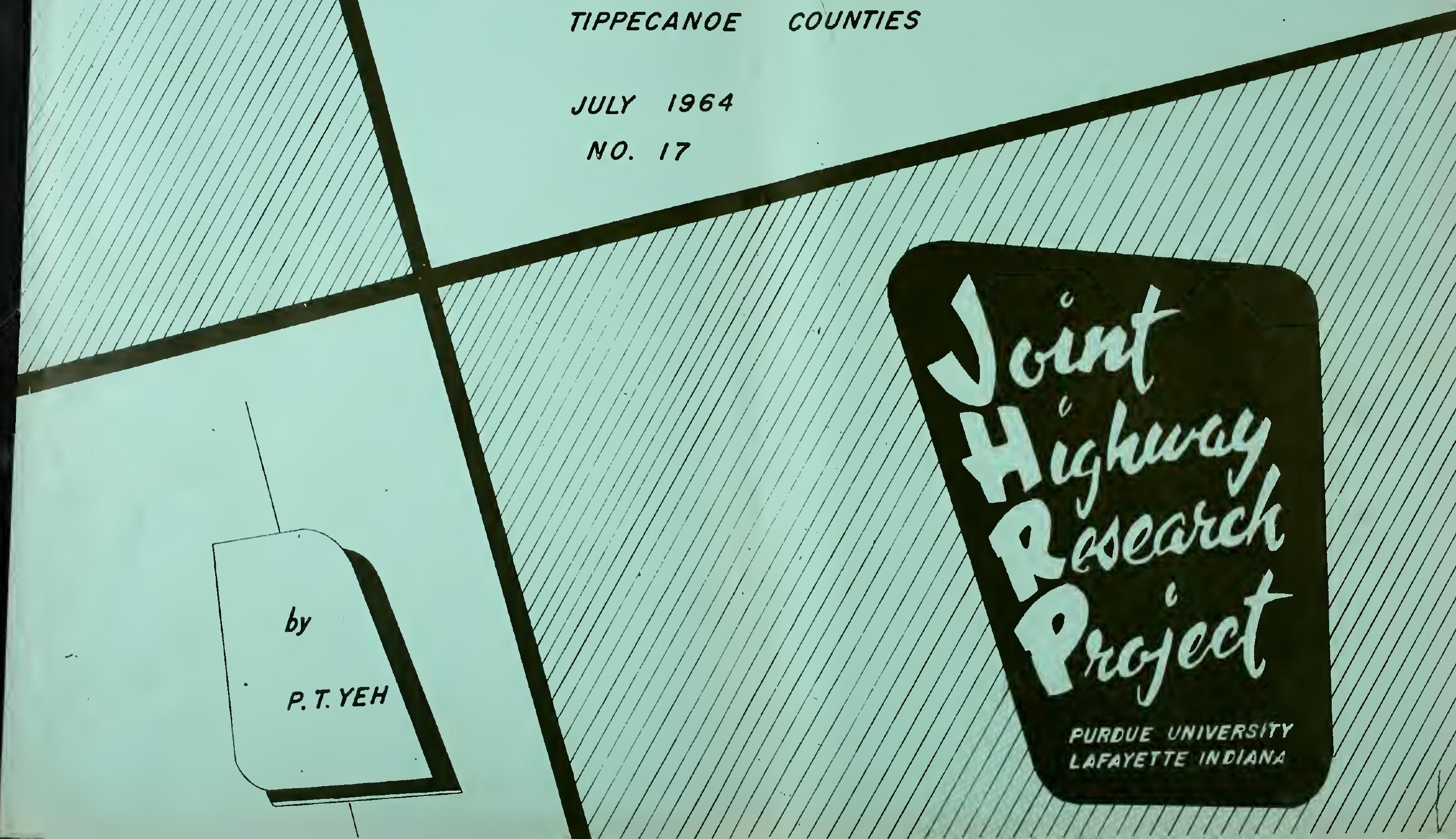




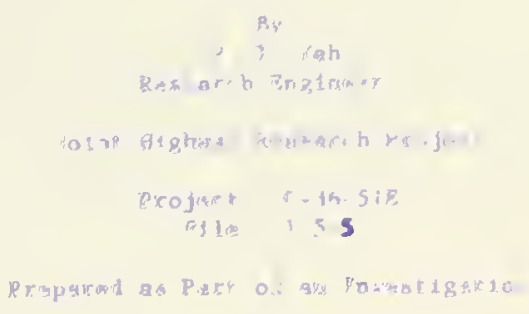

Condur test be

Solsit Eighudy Reswarch Pxoject inglnearing Rapertmot Station

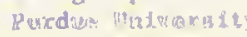

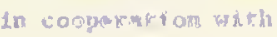

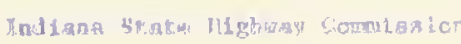

$$
\text { सQ: the }
$$

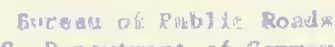

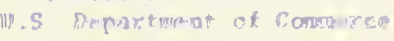

\section{ans to the}

Soll Consazeriton Service

U.S. Departmon of Agriculturu
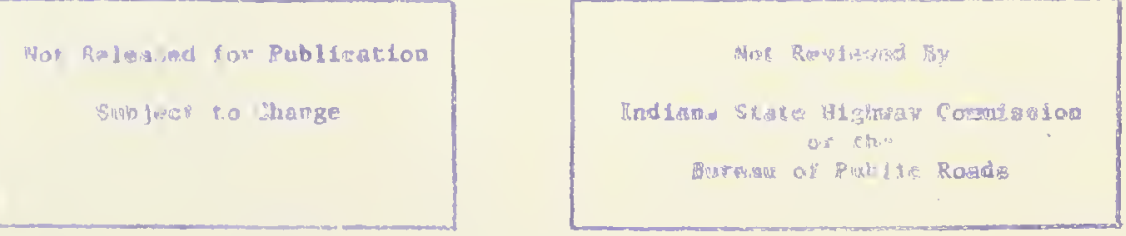

Purdue Bniveraxty

aflaye

Ju1v 22, 1964

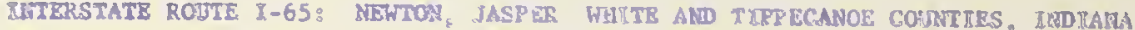

TO: R. B. Woods, Dixector

golnt Highway Research Projese

ROAf: H. L. Hehas, Aseociale Direcion

Jolnt Highvav Reaensch Project

July 22, 1964

File: $1-5-5$

Projart: $\quad C-36-518$

The attached report entitied "Alrphoto Interpratation of Englaesing Sol1s of I-65: Newton, Jasper, White and Tippocanoe Count of as, Indiama," cosmletes a portion of the project. concerned with engineering aolle. mapplng of the Interatate sygtex fical aerial photographs. Thim profect. was prepared as a part of un lavosilgetion conducted by Jolnt: Highwav Research Project in cooperation with the l'adiana Stete Highway Cominolon, the Soll Conservation Servira and the Rurcau of Public Ronds. The tepart was prepared by P. To Xeh, Regenrch Zngineer, Jolot: Highway Reseurcit Rraject.

The soll mapping of $\$-65$ between Kankatea River and SK43 was don

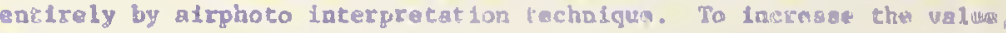
the soll serip map was prepered oa a photogrsph10 anse w1:h anotreiton to ahos soll areng. The generalized soll profilan were prepared from chis avalloble literature.

Respect fully gubmilted

$$
\begin{aligned}
& \text { 21:7 mextart } \\
& \text { H. Is . Michare \& } \\
& \text { Assoclate Director }
\end{aligned}
$$

Fuld: ast

Attrachrent:

Copy 8

F. Lo. Ashbaucher

I. R. Cooper

W. L. Dolch

W. H. Costz

F. F. Havey

P. S. H111

G. A. Leopard
3. B. Mclaughlin

R. D. Mles

R. E. Milla

J. V. Sary the

R. J. Yodar 
IHTRODUCTION

This report and series of photographic strip maps presents the sirphoto interpretation of engineering soils for section of Interatate 65 frow the Kankakee River at the aorthern border of Hewton County southeast to SR 43 about five miles worth of Lefeyette In Tippecenoe County. The eection includee perta of Newton, Jesper, White and Iippecanoe Countiea, Indiene. The photographic etrip map portrays en aree ebout one end one helf milen wide on each olde of the center line elong the proposed roúte.

Digitized by the Intern\&atrchive

Unrectified eerial photographe of e acele of 1/20,000 obcasned in the area of latereat alodg L-65 atarte at the Kankakee River on

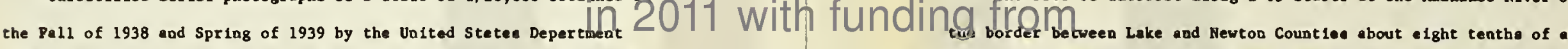

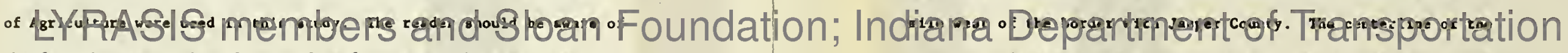
the fect thet meny culturel or aurface feeturee in the area have cheaged alace the ceriel photography wan takea.

The aeriel pbotographic atrip map 16 preaented at a moelic at en approximate acale of one inch represent10g 1500 feet $(1 / 18,000)$. since urectified aeriel photographe ware unad the aerial moealc may not be matched perfectly from one to the other.

The engineerlog 0011 mape were prepared by alrphoto interpretetion methode. The procedurea uned are oimiler to thoee employed in county mapping projecte previounly completed by the ateff of the Joint lighwey

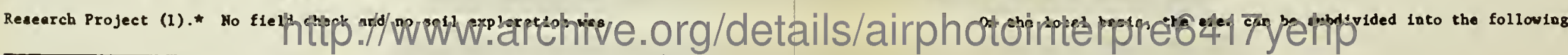

mede for thie mepping study. However, avalleble literature concerniag th1. aree was wearched and uad to complement the 1aterpretation (2). Rafereace was made to the egriculturel Soll Survey for Newtod County (3) Iippecano County (4) and White County (5); The Pormation, Diatribution and Engineering Characteriatics of Soll (6); and two airphoto Interpretation thesie $(7,8)$.

\section{DESCR IPT ION OF AREA} route extends almost due south for about $14 \mathrm{milea}$ thes heeds aoutheeaterly toverd Lafayette. The section ande at SR 43 about five milea north of Lafagette in Iippecanoe County. The atrip in sbout three wilee wide end approximately 50 milea long. Physlography

The entire ares of interant is altuated in the Central Lowlend Province of the United Stetes (9). The northern pert of the aree of study is located on the Morthern Moralne and Lake Section and the southern portion is Included in the Till Plain Section (9).

\footnotetext{
* Pigurea in parentheaen refer to references appearing in the bibliography
} 
sections: the Kankakee Babin, the Marsallles (Iroquols) Moralne, the Iroquols Lacustrine Section and the Tipton Till Plain. Several end moraines (undifferentiated) occur as local ridgea In the Tipton Till Plain section.

Topogrephy

The overall topography of the area is a relatively flat plala. Locally, bowever, the topograpby varlee from a nearly level lowland to and dunes or moralnes rloing 30 feet or more above the ground surface. Undulating to rolling topography may be found in the moranic aections. In the Iroquols Lecustrine section the topography 10 nearly level. A gently undulating eurface is exhibited on the Tipton Till Plain especielly in thite County.

The northern end of the route starts at an elevation of about $640 \mathrm{ft}$. above sea level at the Kankakee RIver and gradually Increaes to $700 \mathrm{ft}$. on the Maraallles Moraine. The grade then descends to an elevation of about $650 \mathrm{ft}$. at the Iroquols River and again Increages to about the $700 \mathrm{ft}$. elevation on the till plain section near Goodland. The proposed route then gradually rises to an elevation of about $750 \mathrm{ft}$. before $1 t$ drope to an elevation of $600 \mathrm{ft}$, near the Wabash River. Geology

The surface materials of the study area are chlefly the reault of glacial deposition. Subsequent wind and water action has modified sose of the deposits to a considerable extent. The bedrock geology 18 of academic interest only because no rock exposure is known to outcrop along the route. The underlylng bedracks are primarily of Devonian and Silur lan Age. However, a small portion of the route in Jaaper County overlies bedrock (sandstone) of M1ssissipplan Age. Bedrocks are deeply covered in the section within Tippecanoe County (10). They are expected to vary in depth from less than $50 \mathrm{ft}$. to more than $150 \mathrm{ft}$. In the northern portion of the route. The thinest overburdene are expected near the Iroquola River and along the creek near Remington 1n Jaepar County (11). Mostly limestones, dolomites and shales ore expectad at depth within the ares of survey.

The unconsolidated surficial materials were deposited by several different substages during the Wisconsin glacial period. The Tipton I111 Plain section is associated with the Bloomington Moralnic Syatem of the Early Wisconsin period (9). The Marsallles (Iroquols) Moralne and assoclated till plain Moralne were the producta of the late Wlaconsin glactal deposit (9). Wayne Includes all of there glacial drifte in the Trafalgar formation (12). The glaclal drift material 18 composed of unstratified boulders, gravel, sand, ollt and clay. In some areas, a thin loess mantle was deposited by wind on top of the glacial drift.

Extensive glaciafluvial outwash deposits were formed south of the Valparalso Moreine. Thls outwash material is a stratified coerse to medium-textured sand with little or no gravel. Many and ridges or dunes were formed within the area. The outwash and dune facles are in the Atherton format Lon proposed by Wayne (12).

Between the Marsallles (Iroquols) Moralne snd the Tipton Till Plain there is a lacustrine deposit. This lacustrine materlal was 
depoeited over drift wateriel aimiler to that forming the Tipton Till pla1n. The depoeit 1a compoesd chiefly of sand and sit and 18 reletively thin. Sand dunes ware formed to this area also. This depost 18 also included in the Atherton formation of Wayne (12). cilmate

The atudy area 18 situated in a continental, humid and temperete belt. There is wide varietion in temperature during the year (from $-33^{\circ} \mathrm{F}$ to $\left.105^{\circ} \mathrm{F}\right)$. The extramea of temperature are usually of short duration. Rainfall 1. fairly well distributed throughout the year. The average annuel precipitation 18 about 38 inches.

LAND PORMS AND ENGLNEERING SOLL AREAS

Engineering so1le along the proposed route of 1-65 are, in general, andy in texture in the northern portion and silcy clay 10 texture in the southern half. Variation in the soll profiles 18 expected as the land forms change or as topography veries on the spectfic land forms.

Twenty-one soll areas are differentiated and numbered as such on the eagineering soll atrip maps attached. The soll areas generally designate land forma such as outwash plains (1 and 2), duaes (3), ridge moraines $(6,7)$, ground moraines $(9,10,11)$, lacustrine platns $(14,15)$, terraces $(16)$, floodplaine (17), depresefons $(18,19,20)$ and skers or kames (21). A few aoll areas represent transttion zones such as dunes on lacuatrine or glecial deposits $(4,5)$ or $10 e s s$ on 8lactel deposits $(8,12,13)$. Because of algnificant topographic differences within certain land form areas, a total of 33.011 profiles are portrayed. These profiles are belleved to be representative of soll conditions expected along the proposed route.

The discussion that follows la a brief description of esch aoll area portreyed on the aerial photographic atrip mapa.

1. Sandy Outwash Deposit

This deposit occurs at the northern part of the section and 18 designated as soll area 1. It 18 the major soll in the Kankakee Outwash Flain. The topography of thia depontt 18 nearly level. No natural surface drainage syatem 1s found on thia depost; however, drainage ditches are commonly used to lower the ground water in this area.

The surface soll as shown in soll profile 1 varies from fine sand to fine sandy loam with comparatively high content of organic matter at the surface in the olightly lower topographic postitions. The subsoll ta a rather uniform sand classifted as A-3 soll.

The major engineering problem in this soll area 1s that of drainage.

2. Sandy Outwash Deposit, Organic

These soll areas are associated with the sandy outwash deposits and are shown as area 2 on the maps. They occupy the lowest topographic position on the Kankakee outwash plain.

The surface soll to a fine organtc sand or organic fine sandy loam that may extend to a considerable depth. The organic content 1a highest near the surface and generally, decreases with depth. In some areas, a layer of muck may be found benesth the organic sandy surface soll. The subsurface soll is a loose sand clessified as A-3 
so11.

Due to the unfavorable topographic position this deposit is poorly drained. Humerous dralnege ditches are employed to reclaim this low, swampy land. The major engineering problem involved in thia soll area to esseatially the problem of lowering the water table.

3. Sand Dune Depoalt

The sand dune deposits are concentrated on the Rankakee outwash plata and the Iroquols lacustrine plain in the northern and central portion of the route aurveyed. The dunea are irregular and appear in many forms. Ridge type dunes are most coumon in thia area. However, creacent shapea and even mound shapes are found. The dunes vary in height from a few feet to 30 feet or more. Many of the dunes are atill active today. The dunes are outlined with dotted 1 ines and are marked with the aymbol 3 .

Soll profile 3 shows that a uniform sand (A-3 soll) is found a long the dunes where the deposit of the windblown material is deep. Occasionally a faintly coherent fine sand la developed with layer of loose sand below the surface. Near the toe of the sand dune an organic fine sand or organic fine sandy loam is found on the surface. A sandy loam texture 1 found beneath the organic surface soll and this grades fnto a looke sand. At variable depths beneath the surface, the buried organic sand of the outwash plain or the plastic soll of the glacial drift 18 found depending on where the and dune is located.

Cuts are generally required through the dumes but the sands are deep and no change in texture is lovolved. A definite problem with these ands is the matter of atabilization as the and is ausceptable to wind erosion.

4. Inclplent Sand Dune Depoalt

The incipient sand dune areas (mapped as area 4) are regloos where some wind erosion and deposition has occurred but no distinct dunes have formed.

The most extensive Inciplent sand dune deposit lies on the northern end of the route within the Rankakee Outwash Plain. This deposit is interopersed with the low lying, organic, sandy outwash depoefta on one hand and the high, irregular or fented, sand dune depoatts on the other. Other Incipient sand dune deposits are loceted along the southern border of the Iroquols lacustrine plain and further south on the ground moraine. The inciplent and dune deposit has an undulating to slightly rolling topography.

The soll profile on the high shows that the surface soll varies from fine sand to organic fine sandy loam. The subaofl is generally a loose medium and or fine and. However, a aady clay loam may be found which in turn reata on a loamy-textured glaclal drift. This situation 18 common in the area bordering the ground morsine. In the depresslons, a deeper, organtc, andy loam topsoll is usually found overlying the sandy subsoll.

Two soll samplea (No. 2308 and 2309 ahown on the map) were previously obtalned in White county (8). Sample No. 2308 was secured near the southwest section corner of section 13, T.26N., R.6W. 
The other site 18 located about two miles east. Sample No. 2308 was taken three feet below the surface while sample No. 2309 was obtained approximately five feet below the ground surface. Both samples show less than $81 x$ percent of fines and se identified an aon-plastic sand that is clessified $28 \mathrm{~A}-3$.

\section{Sand Dunes on Ridge Moralne}

Area 5 represents a zone where windblown sand overlles glacial drift in the form of ridge moraine. The area exhibits an undulating topography with a few saad dunes and shallow deprese100s. The thickness of the sand deposit is generally from three to five feet. Due to the porous nature of the ourface layer, a natural drainage system 1s poorly developed. A fow dreinage ditches exist.

A fine sand of soady lom texture is axpected for the topsoil on the high topograpbic position. The subsolls ere elther sands or sandy loams. The underlylog glecial drift veries from loam to clay $10 \mathrm{am}$.

The topsoll in the depreselons (Low of Profile 5) veries from an organic loam to an organtc silty cley loew. Silty clay and clay are the subsurface materiels. The texture of the drift also varies from - loam texture to a clay texture in this ares.

6. R1dge Moreloe of Silt Loam

Th1s depoeit (ares 6) is located in white County. It 12 a weak ridge moraine surrounded by a ground morsine (soll area 10). The ridge moralne is only slightly higher than the ground moralne sad exhiblte a very gently undulating topography.
The topsoll coasists of silt lon to silty cley loam under timber cover. A high organtc content is expected in the pratrie ares. Subsurface soll varies from silty clay to clay. The glacial drifts var1es from loam, to silt loan to clay loam. In the depreselons, the topsoll varles from orgale ollty cley to an organic cley.

\section{Ridge Mornine of Organic Loan}

Soll sree 7 is the malo ridge of the Marseliles morelae. Th1 region shows unduleting topography. The surface, in many places, is modified somewhat by a layer of send. Occsstonelly sand dunes are formed on this depostt. Surface dreinge syatema (gullies) are better developed in this ares than in aree 5. However, some ditching Is evident.

The surface soll on the highs (profile 7) varlee fron a slightly organfe loem to organic clay loam underlein by clayey subsolls. The texture of the parent material ranges from loan to a clay loam. In the lows, the surface solls are finer in texture and heve a higher percentage of orgenic matter. S1lty clay or clay textures are found in the subsoll. The perent material constats of either a loam, a clay lont or a clsy.

A soll sample taken previously (soll sample No. 2331 in reference 8) shows the sandy texture of the glaclal drift. The soll was sampled at two feet from the surface at a point about one mile east of the proposed route along county road at section 22 an indicated on the map. The sample showed 14.5 percent passing the 200 sleve and a plestic 1 imit of 39.7 percent with a plestic index of 19.3 percent. It 1 s clessified 
28 A-2-6.

The undulating nature of the topography in this soll area indicates that cuts through the shallow sanda and into the underlying drift may be expected. The zone of intersection of different texture 1s likely to show evidences of poor performance.

8. Thin Loese on R1dge Mora ine

A ridge moralne with a thin loese cover occurs in Tippecanoe County. It 18 ahow as aree 8 on the mapa. Undulating to rolling topography is predominent in this area.

The drift deposit is covered by loess with a depth ranging from 18 to 36 inchea. The aurface soll, therefore, 18 generally classified as a silty clay loam, a soll containing a high percentage of silt. The subsoll is clayey in texture. The parent material variea from a loam to a cley loam with increasing amount of sand and gravel with depth. In the depresslons or basins a higher organic content occurs in the surface solls.

9. Ground Moralne of Silty Cley Loam

Severel ground moralnes are differentlated on the aerial photographic atrip mapa. Aree 9 exbraces a depoalt whowing a gently undulating topography with well developed gully syotems.

The topsoll in this soll region varies from a silt loam to a silty clay laem in the high positiona to an organic allty clay texture in the low positions. The aubsoll range from silty clay to clay. The perent material shows a loam or clay loam texture.

10. Ground Moraine of Organlc Stlt Loam
Th1a deposit (area 10 on the maps) 1 lea along the centrel portion of the study atrip. It 18 a large plain that is extremely flat to locally undulating. Natural surface dralnage syatems are not well developed, but man-made ditches occur frequently.

The surface soll varies from a bighly organic allt loam to an organic clay. The subsoil is of a silty clay to clay texture. The parent material 1a till that variea from a loan to a clay.

11. Ground Moraine of Organic Loam

In the vicinity of the function of Jaaper, White and Benton Countles there are a few alightly higher areas of ground moraine show as area 11. The surface soll to coarser than the surrounding ground moralne shown as area 10. It conelste of an organte loam or an organic clay loam. This may be the result of the admixture of sand thinly spread over the silty prairie. The subsoll 1 s clay and the parent material la a loam or clay loam.

12. Loess on Ground Moralne

Along the border between white and Iippecanoe countiea there is an aree (Number 12) of ground moraine that 1o covered with a mantle of loess. The soll is developed under the influence of pratile vegetation. The topography to undulating and many infiltration basine occur.

The loess cover on the ground moraine variea in depth from about 18 to 36 inches. The soll profiles are characterized generally by a slightly organic silty clay topsoll, a clay subsoll and a clay loam parent meterial. However, the topootl may vary from an organic 
silt loam to a silty clay loam and eveo clay depending on the topographic position. The parent material also varies from a loam to a lean clay.

\section{Thin Loess on Ground Moraine}

This deposit occurs near the southern end of the strip in Tippecanoe County. The deposit is essentially the seme as the one previously discusaed except it has developed aotls influenced by timber cover. The soll profile differs from those for area 12 in that a negligible amount of organic matter occurs in the topsoil. The subsoil and parent material are essentially the same as discussed for area 12.

14. Lecustrine Deposits of Sands and S11t

A large lacustrine deposit (soll area 14) 1s located slong the Iroquots River basto between the Marsellles Moralne and the Tipton Till plain. In general it is a large, flat plain. Subsequent wind action hes created well developed sand dunes and numerous incipient dunes. The topography, therefore, is level to gently rolling. Fleld Investigation In Newton County reported by McGregor (7) discloses that the material underlying the stratifled sand and silt of the lscustrine deposit 1s glacial drift. The thickness of the lacustrine deposits varies from place to place. Sometimes the underlying drift is exposed espectally along the rivers.

The surface soll of this lacustrine deposit varies from a slightly organlc andy loaw in the high positions to en organic silty clay in the low positiona. The auboll al ao varies widely from a sandy clay loam to a clay. The parent material is composed of atratified silt and and with thin layers of clay and fine gravel. In the low areas a deeper, more organic, watertel la 11 kely to occur. A soll sample (sample No. 2330 in reference 8) obtained more than four feet from the ground surface at a point about one-half mile west of the proposed route in section $9, T .28 \mathrm{~N}$., R.7W. 11lustrates the saady and silty texture of the deposit. The teat data show that it is a non-plastic A-2-4 soil contalning about 20 percent fines.

\section{Lacustrine Deposits of Clay}

A few sreas in this study atrip can be clasaifled as lecustrine deposits of clay. These aolls occupy low topographic positions within the lacustrine area previously diacussed. The proposed route doen not cross this type of deposit. The soll profile shows thet the surface material varies from an organic allt loam to an orgenic clay. This is underlalo by a clay aubsoll and a clay parent material with thin lenser of send and silt.

16. Terreces

The terraces recognized on the aerial photography in this atudy 211 are located in Iippecenoe County. The larger terraces occur a long the Wabash River. Some smaller terraces ere loceted along Burnetto Creek which is tributary to the Wabsth River. The topographic break between the valley wall and the terrace aurface are consplcuous.

The soll profile on the terraces conslats of a surface horizon thet vartes from sendy loam to allty cley loam. The depth of the horizon varles frow zero on the steep terrace face to about 18 inches on the level surface. The subsoll shows generally an incresse of clay and plasticlty with respect to the layer ebove. The amount of and 
and gravel increases with depth. The parent materiala are atratifled aenda and gravela.

\section{Alluvial Plelne}

All drainage channels in the area surveyed poseas recent alluvial platas or floodplaina. The largest floodpla1a la located in Newton County along the Kankakee River. The tream channels frequently have been atralghtened by ditching eapecially elong the Kankakee River and along Cerpenter Creek and Curtia Creek, both tributeries of the Iroquola River.

The texture of the alluvial deponita varies greatly from one plece to the other depending on the nature of the dralnage baln. The ourface a oll variea from a sendy loam to a lit loam or a clay loam. In the swalea and depreseions of the floodplain a highly organic silty loam, allty clay loam, silty clay or clay topsoll may be found. The suball varies from a sit loam to a ally clay or atratified allt, and and clag may be present. Occesionally the subsoll may contain thin layers of sandy or gravelly materlal. Along the major rivera caarse textured deposito frequently occur at depth. A sandy texture 1a found at ehallow depth throughout the Kankakee R1ver floodplein.

\section{Organle Depreselons}

Many suall depresofions in the study area are mapped as organic depresilons. They are the results of accumulation of organic matter in poorly dralned topographic positions. The majority of theae areas accur on the ridge moralne and on the ground moraine located in
Tippecanoe County. A few are identified in the sandy outwash areas.

The soll profile conalot of an organic allty clay or orgenic clay topsoil, a plastic silty clay or clay subsoll and a clay or clay loam parent material.

19. Muck and Peat Deponits

Most of the muck and peat deposits are located on the ridge and ground moraines mapped along the route in Tippecanoe County. In fact, the proposed route crossea a few large deposits just south of the Tippecanoe County border. Others are located on the Kankakee Outwash plain near the Kankakee River and a few occur on the Iroquols lacustrine plain. Most of the peat is derived from mosses, sedgea and wood. In some kettles, a soft layer of mar1, ranging from a few laches to 12 inches or more in depth, is found under about 12 to 42 Inches of muck. The marl is an earthly material compoaed principally of an amosphou form of calcium carbonate. Since it 18 also undesireble from the engineering standpoint, no separation to made from the pest and wuck in the soll profile lllustrated.

The depth of these cumulose deposits varies greatly from one location to another; therefore, field investigation of each individual depasit is required. Treatment of each deposit will be directed accordingly.

20. Clay Depreseions

The clay depresstons are mapped withtu the portion of the route in Tippecanoe County. They occur in the deeper parts of the elongated swales and depressiona and in some of the shallow kettles. 
The surface soll ta a highly plastic clay containing very little organic matter. The subooll as well as the pareat materlal are essentially the same as those mentioned for area 18 .

\section{Eikera and Kanes}

Only a few eakers and kames are located in the study route. All of them are located in the southern portion. The proposed route crossea one near the border of White and Tippecanoe Countlea. The eakers and kames are low ridges and hills and are not conspicuous.

The wolls developed on eskers and kames vary considerably. The surface horizon varies from a sandy loaw to a silty clay loam. In areas of aevere olope erosion the surface aoil may be entirely removed and the subsoll exposed. The subsoll varfes from a clay loam to a clay with varying amounts of sand and gravel. The amount of sand and gravel increases very rapidly with depth. Clean atratified, coarse material is found in the parent material zone and sand textures predominate in the study region.

\section{SUMMARY}

The proposed route starts at the Kankakee River near the northeastern corner of Newton County. It proceeds aoutbesstward across the floodplafi onto the candy outwash plain. It then crossea well defined sand dune (Area 3) and enters the inciplent sand dune area. About one mile after crosing the Newton-Jasper county line the route heads directly south and crosses another narrow, sandy outwasb plain with organic surface soll. and reenter. zone of inciptent sand dune deposita. The route alternately crosses outwash plains, dunes and areas of organic surface solla until it encounters the glacial drift surmounted with sand dunes (Area 5). This deposit of sand continues for a distance of about $2 \frac{1}{2}$ miles as the route proceeds southeasterly. The rolling topography cont Inues along a segment of the Marsellles Moraine designated as Aree 7.

The route then traverses the sllghtly undulating Iroquols Lacustrine Plain for a distance of about 9 miles. Within this plain, the route crosses a number of sand dunes and the floodplatins of Corpenter Creek and the Iroquols River. On the aouthern edge of the lecustrine plain sn area of dunes is crossed about three miles north of Remington.

The proposed route then enters upon a large ground moralne that extends for sbout elght miles. Much of the soll of this ground moralne developed under a prairie condition and organic content of aurface so11s may be high (Ares 10, and 11).

Purther to the south, superimposed on the ground moraine, sand dune srea (sbout one mile wide) accurs in white County. The route then contiaues on the ground moraine for another few miles. Southesst of the proposed crossing of U.S. route 231 a low ridge moraine (Area 6) 1s encountered that extends for about two miles. The route continues across another ground moralne for (Area 10) several miles. A portion of this ground moraine exhibits a loess cover degignated as soll axes 12 . About two miles north of the WhiteTippecsnoe County line, aw esker is crossed. This esker lo sandy in texture.

A loess covered ridge moraine (So11 aras 8) la encountered 
shortly after the route enters Tippecanoe County. Within the ridge moraloe, several small muck deposits sre crossed. South of the ridge moraine the route 18 located on a gently undulating, loess covered, ground moraine (So11 area 13) for a distance of about three milea. It crosses a large muck deposit shown as ao11 ares 19 and the narrow floodplain of Burnetts Creek. South of the creek the proposed route Ifes on a fine textured ground moraine (Area 9) which continues to the end of the project at the intersection of SR 43 .

\section{ACKONOWLDGIENTS}

All afrphoto used in connection with the preparation of this report sutometically carry the following credit lines: "photographed for Onfted States Department of Agriculture."

\section{BIBL TOGRAPHY}

1. Miles, R. D. "Preparation of Engineering Solla and Drainage Survey Strip Maps from Acrlal Photographs," Engineering Bullet in, Proceedings

2. Yeh, P. T., "Alrphoto Interpretation of Engineerfing Solls of Tippecanoe County Ind iana", Report No. 19. Jo1nt H1ghway Research Project, Eagineer1ng Experiment Station, Purdue Univeraity in cooperation with Indiana State H1ghway Commiasion, Bureau of Public Roads, and the Soll Conservation Service, July, 1963.

3. Buehnell, T. M., et a , Soll Survey of Newton County, Indlana, Onited States Department of Agriculture, Soll Conaervation Service in
Cooperetion with the Purdue Univeralty Agricultural Experiment Station, Seriea 1941, No. 14, March, 1955.

4. VIrich, H. P., et 21 , Soll Survey of Tippecanoe County, Indiana, United States Department of Agriculture, Sofl Conservation Service in cooperation with Purdue Univeraity, Agricultural Experiment Stet100, Serfes 1940, No. 22, Jenuery 1959.

5. T. M. Bushnel1 "So11 Survey of thite County" 20th Annuel Report of Department of Geology and Natural Resourcen, Ind1ana. 1955.
6. Belcher, D. J., Gregg L. E., and Woods, R. B., "The Formation Distribution and Engineering Characterfatics of Solls," Bulletin
No. 87, Engineering Experiment Station, Purdue University, 1943.

7. McGregor, D. D., "Bnglneer Ing Interpretation of Agricultural Soll Maps and Correlation with Alrphoto Patteras," A thesis, Purdue University, School of Civil Engineering, 1956.

8. Johnson, A. M., "Alrphoto Interpretation and Englneering Evaluation of Northwest Indiane Sanda" A theels, Purdue Univars1ty, School of Civil Bngineer1ng, 1949

9. Logan, W. N., "Handhook of Indiana Geology," Ind fane Department of Conervation, State of Ind lana, Indianepolis, Indiane, 1922.

10. "Ground-water Resources of Tippecanoe County, Indiene," Bulletin No. 8 Ind Iana Depertment of Conservation, Divialon of Water ReBources Ind Ienapol 18, Indiana, (Appendix 1956) 1958.

11. "Thickness of Glactal Drift In North Central Indiana" Circular No. 1, Indiana Flood Control and Water Resources Comisesion, Indienepolis, Indiane 1950 .

12. Wayne, W1111em J., "Ple1stocene Formationa In Indiana," Bulletin No. 25, Geological Survey, Indiane Depertment of Conervation, 1963. 
SOIL CLASSIFICATION AND PROFILE SMMBOLS

\begin{tabular}{|c|c|c|c|c|c|c|}
\hline \multirow[b]{2}{*}{ Description } & \multicolumn{4}{|c|}{ Grain Size Distribution } & \multirow[b]{2}{*}{\begin{tabular}{|c} 
Plastic \\
Index
\end{tabular}} & \multirow[b]{2}{*}{ Symbol } \\
\hline & $\begin{array}{c}\text { Gravel } \\
\% \text { Retained on } \# 10\end{array}$ & $\begin{array}{c}\text { Sand } \\
\$ 10-\$ 200 \\
F\end{array}$ & $\begin{array}{c}\text { Silt } \\
0.05-0.005 \mathrm{~mm}\end{array}$ & $\begin{array}{c}\text { Chay } \\
\text { Less than } 0.005 \mathrm{~mm} \\
\end{array}$ & & \\
\hline Gravel & $85-100$ & $0-25$ & $0-20$ & $0-10$ & of & $\because \because \because 0$ \\
\hline Sardy Gravel & $50-85$ & $15-50$ & $0-10$ & $0-10$ & $6 \mathrm{Max}$. & {$\left[\begin{array}{lll}0 & 0 & 0 \\
0 & 0 & 0\end{array}\right.$} \\
\hline Sand & $0-15$ & $85-100$ & $0-10$ & $0-10$ & $\mathbb{M P}$ & $\because \because \therefore]$ \\
\hline Gravelly Sand & $20-49$ & $45-85$ & $0-10$ & $0-10$ & $6 \operatorname{Max}$. & 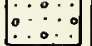 \\
\hline Sandy Loam & $0-19$ & $50-80$ & $0-50$ & $0-20$ & $6 \operatorname{Max}$. & $\%$ \\
\hline Sandy Clay Loam & $0-19$ & $50-80$ & $0-30$ & $20-30$ & 10. $\operatorname{Max}$. & $7 \%$ \\
\hline Sardy Clay & $0-19$ & $55-70$ & $0-15$ & $30-45$ & 11 Min. & $\because \cdots$ \\
\hline Loar & $0-19$ & $30-50$ & $30-50$ & $0-20$ & $10 \operatorname{Max}$. & ED \\
\hline Silt Loam & $0-19$ & $0-50$ & $50-100$ & $0-20$ & $10 \mathrm{Max}$. & EXI \\
\hline Silty Clay Loan & $a_{-19}$ & $0-30$ & $70-100$ & $20-30$ & $11 \mathrm{Min}$. & 40 \\
\hline Silty Clay & $0-19$ & $0-15$ & $55-70$ & $30-45$ & $11 \mathrm{M} n$. & 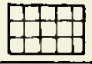 \\
\hline Clay Loam & $0-19$ & $20-50$ & $50-80$ & $20-30$ & $11 \mathrm{Min}$. & $B A$ \\
\hline Clay & $a-19$ & $0-55$ & $0-55$ & $30-100$ & $11 \mathrm{M} n$. & \\
\hline \multicolumn{7}{|l|}{ Feat or Muck } \\
\hline Lime stone & & & & & & (193 \\
\hline Sand rtone & & & & & & $\begin{array}{ll}1 & 1 \\
1 & \end{array}$ \\
\hline Shale & & & & & & 19 \\
\hline Stony Fragrents & & & & & & 象 \\
\hline Organic Matter & & & & & & $=-$ \\
\hline Top soil & & & & & & \\
\hline
\end{tabular}

Classification of Gravelly Soils

858-100\% gravel plus finer material - Gravel
$50 \% 04,8$ grave 1 plus finer material - Clayey, silty or sandy gravel
$202-498$ gravel plus finer material - Use fine classification and called

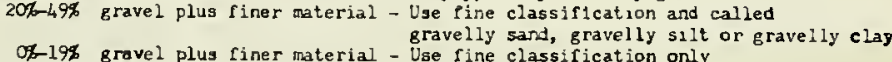

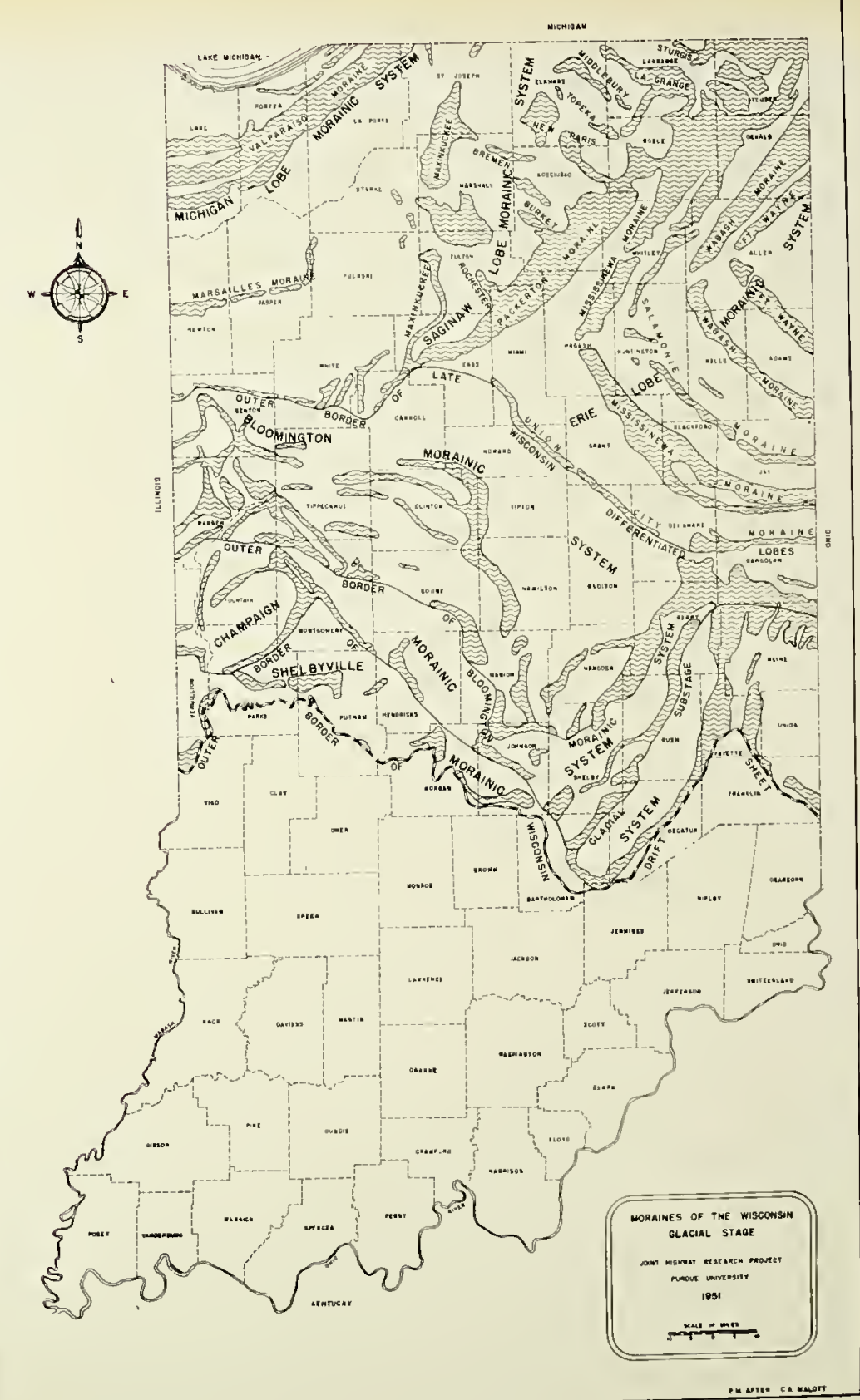

cusue canerr 


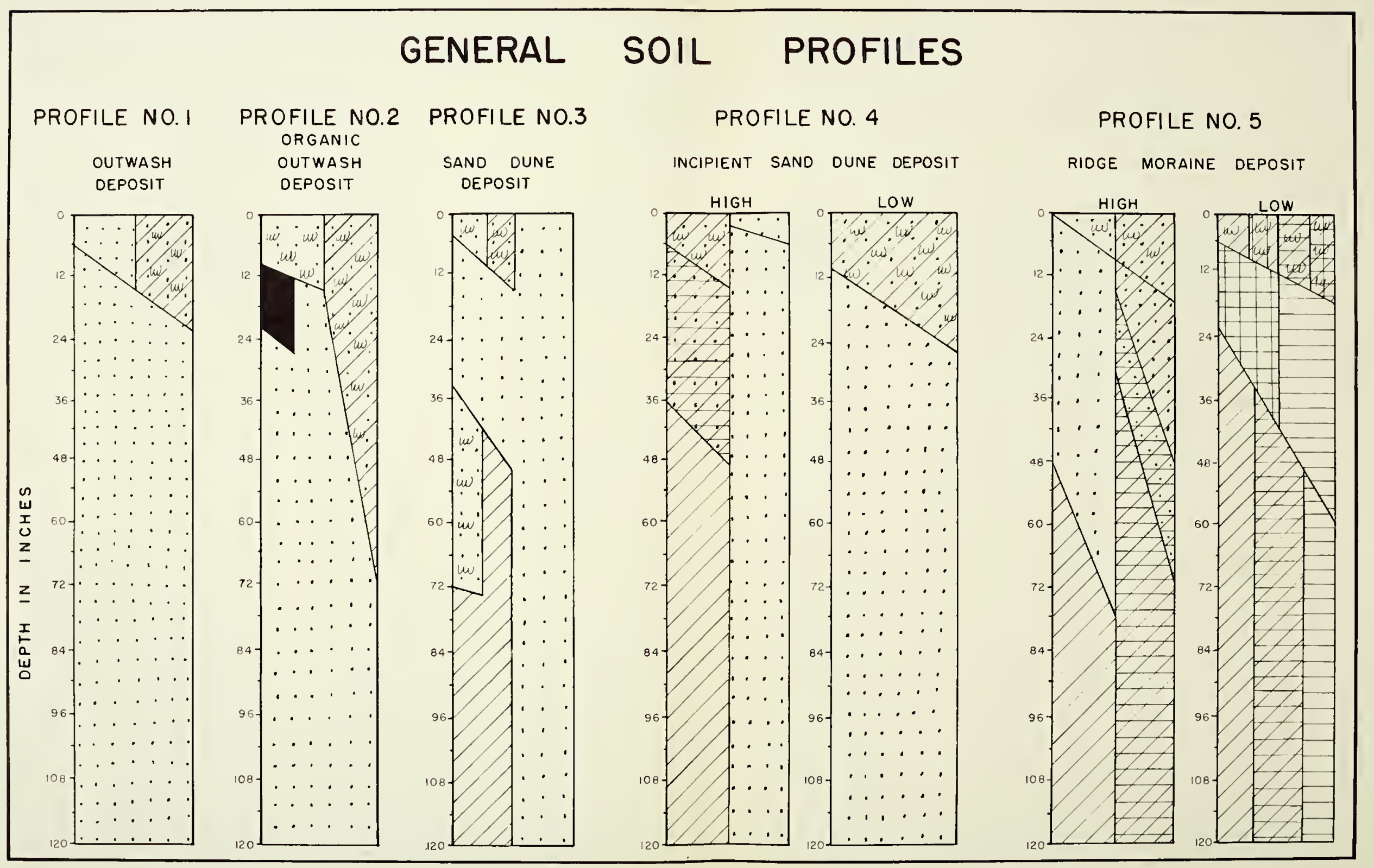




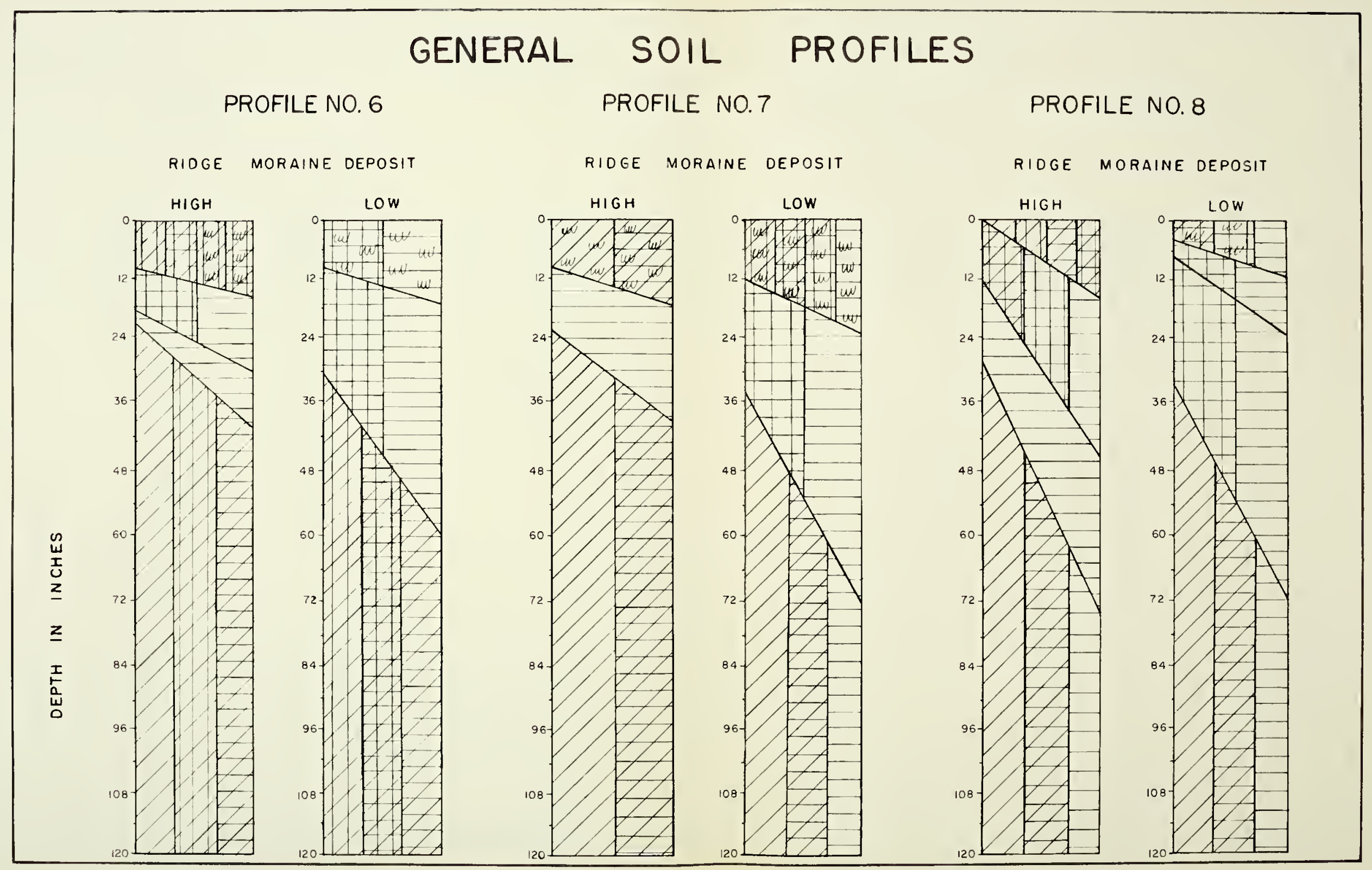




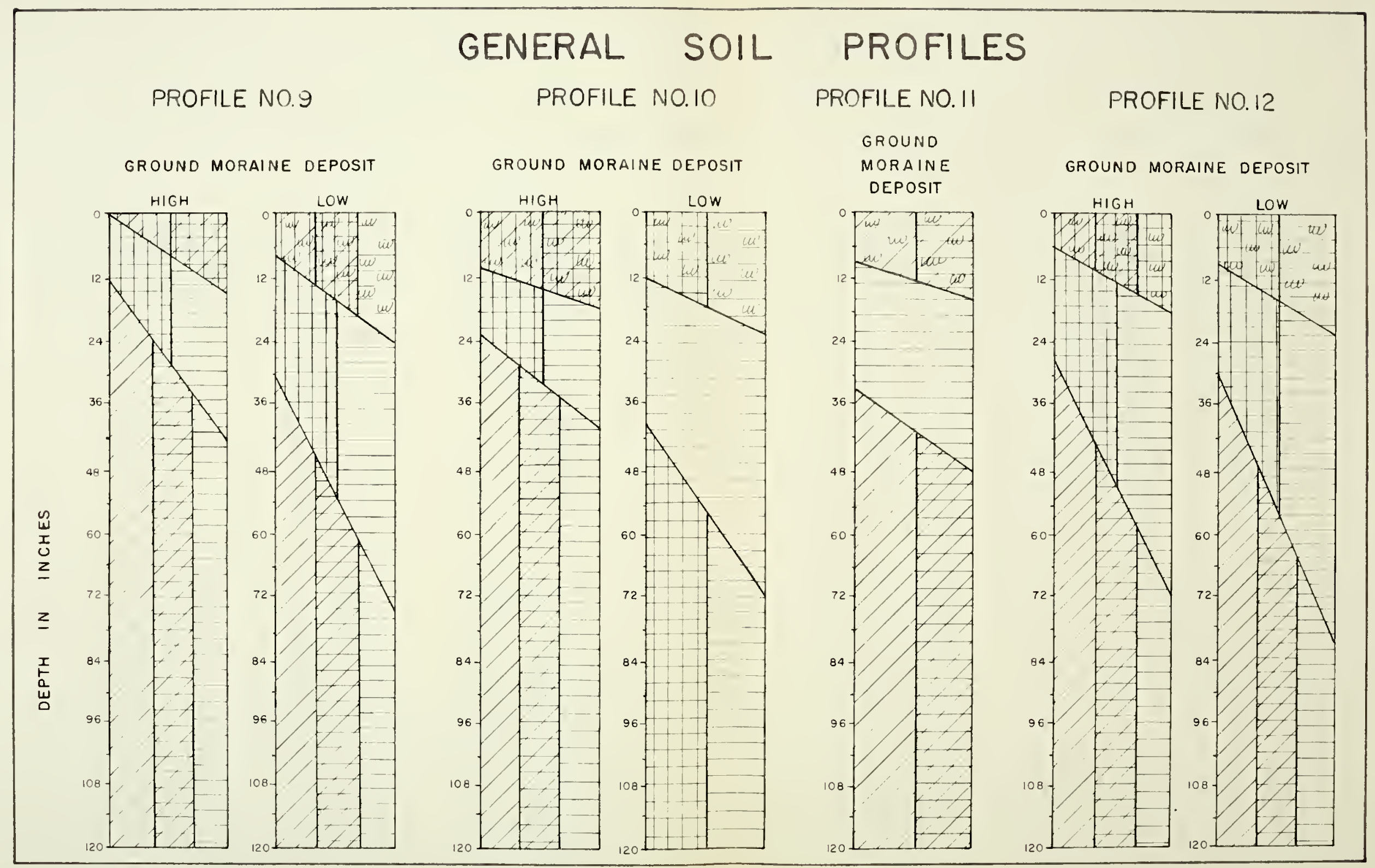




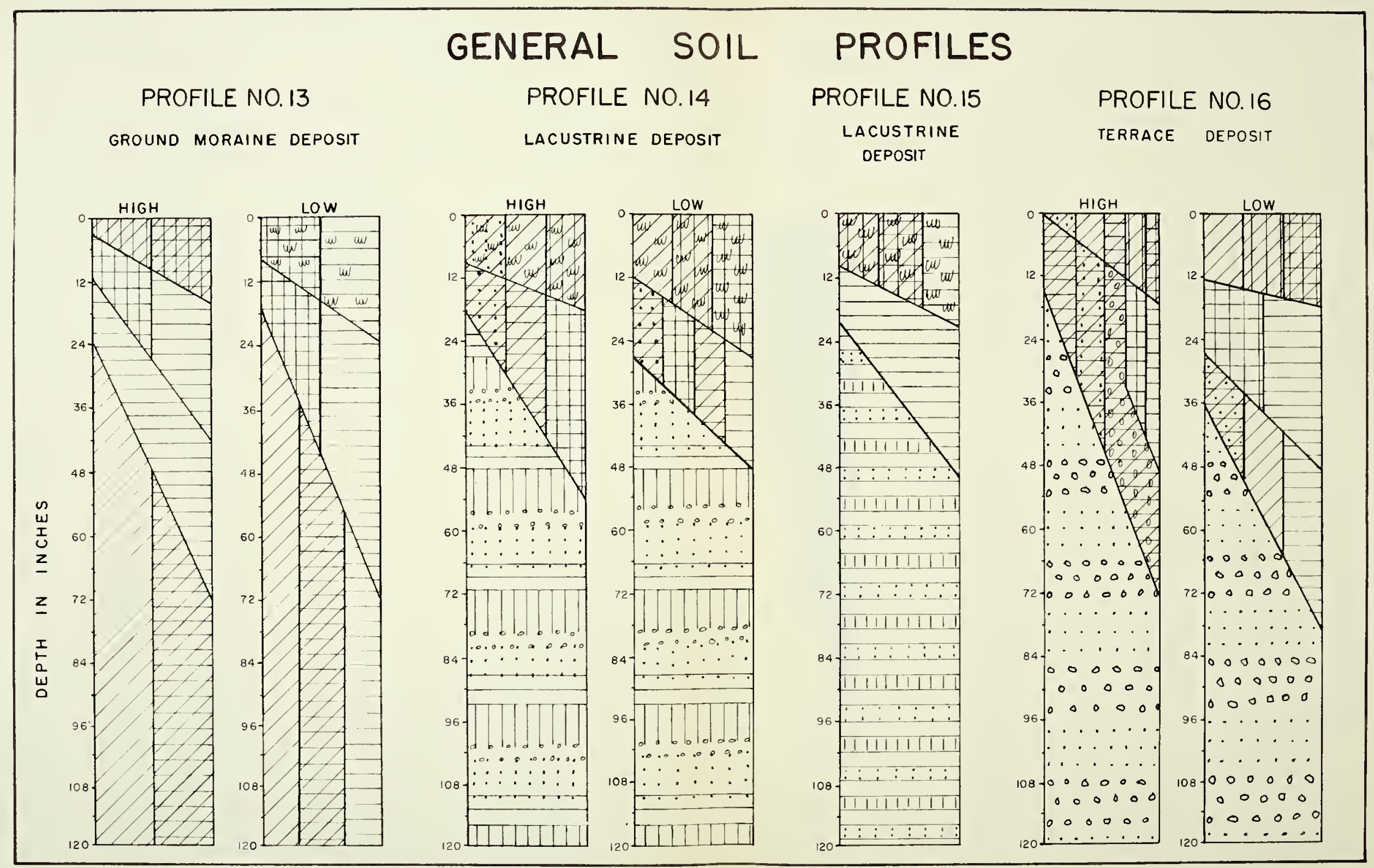




\section{GENERAL SOIL PROFILES}

PROFILE NO. 17

ALLUVIAL PLAIN DEPOSIT

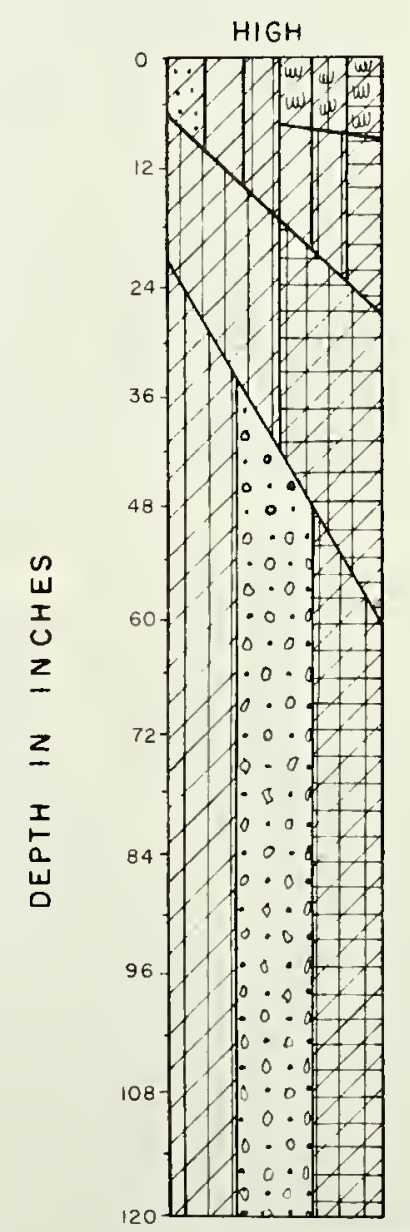

PROFILE NO. 18

ORGANIC DEPRESSION
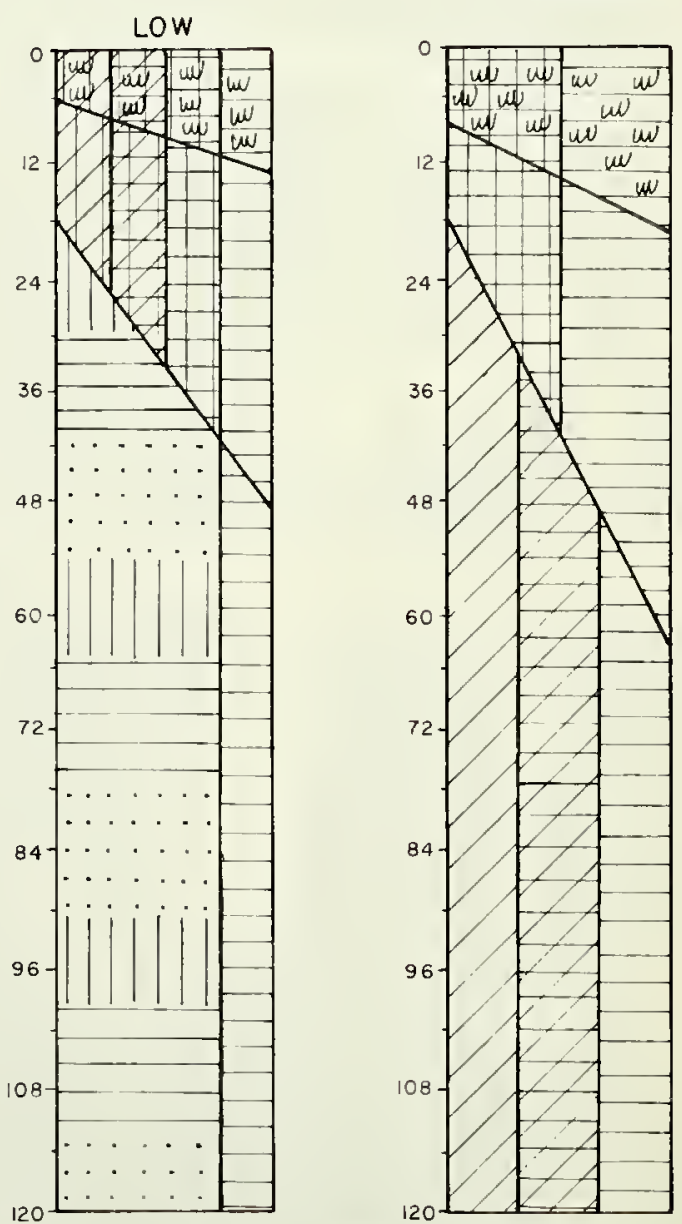

PROFILE NO.19

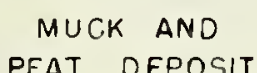

PROFILE NO.20

CLAY DEPRESSION
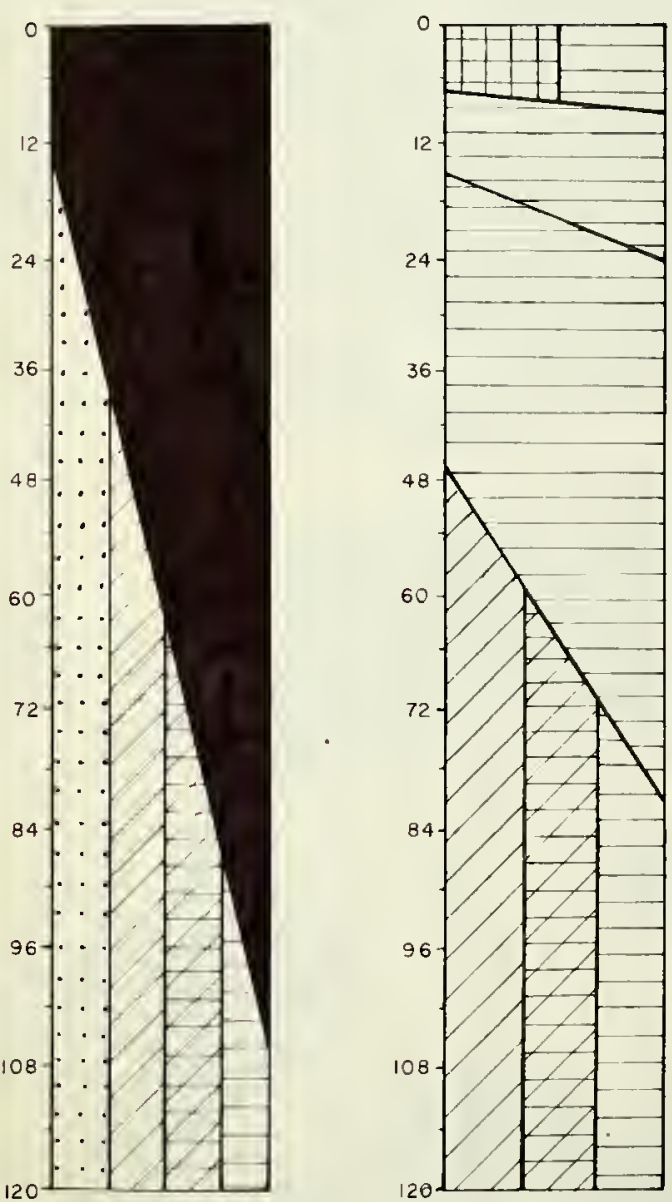

PROFILE NO. 21

ESKER AND

KAME DEPOSIT 


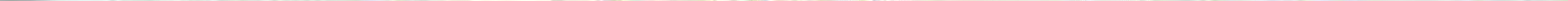




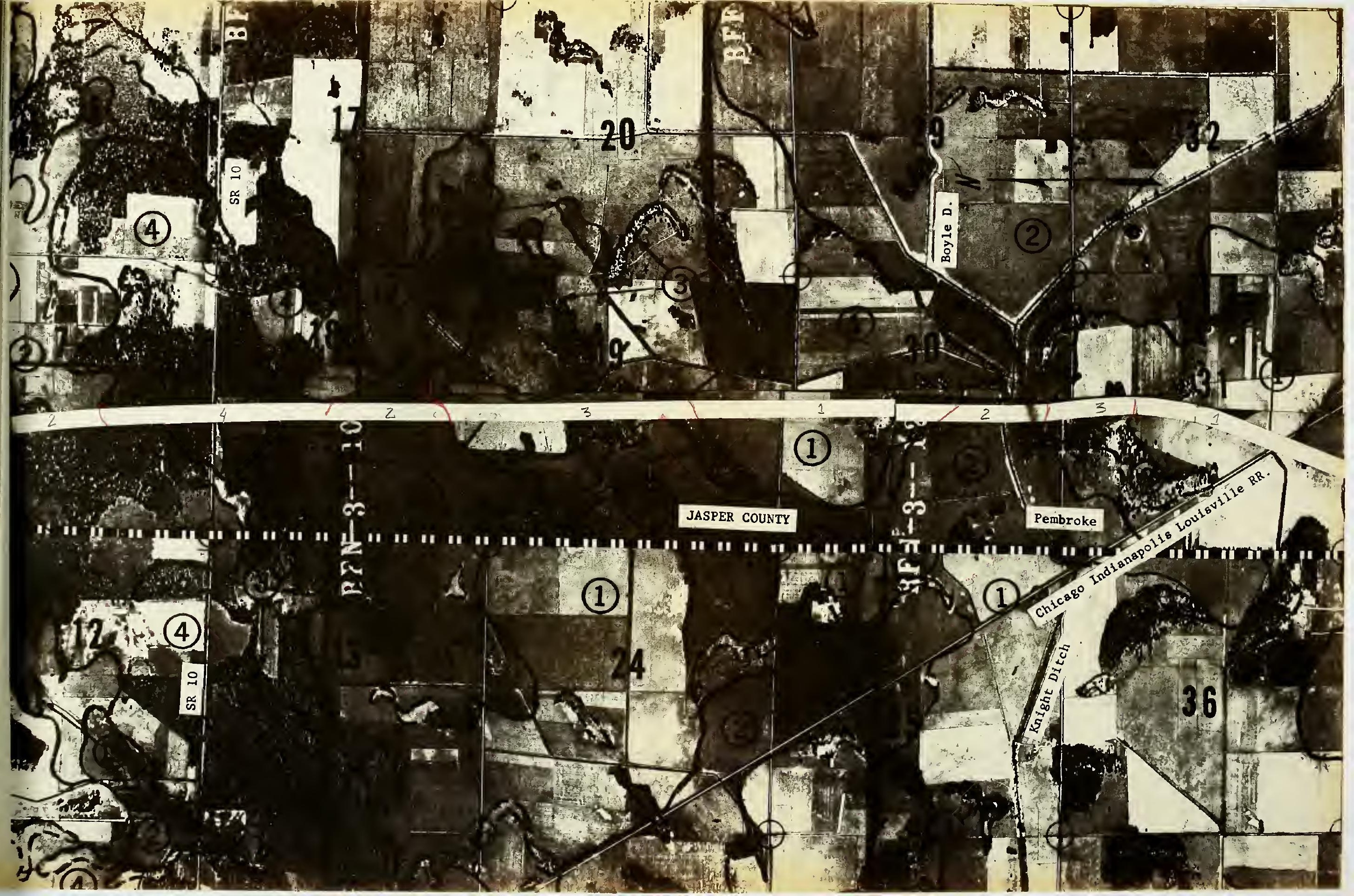



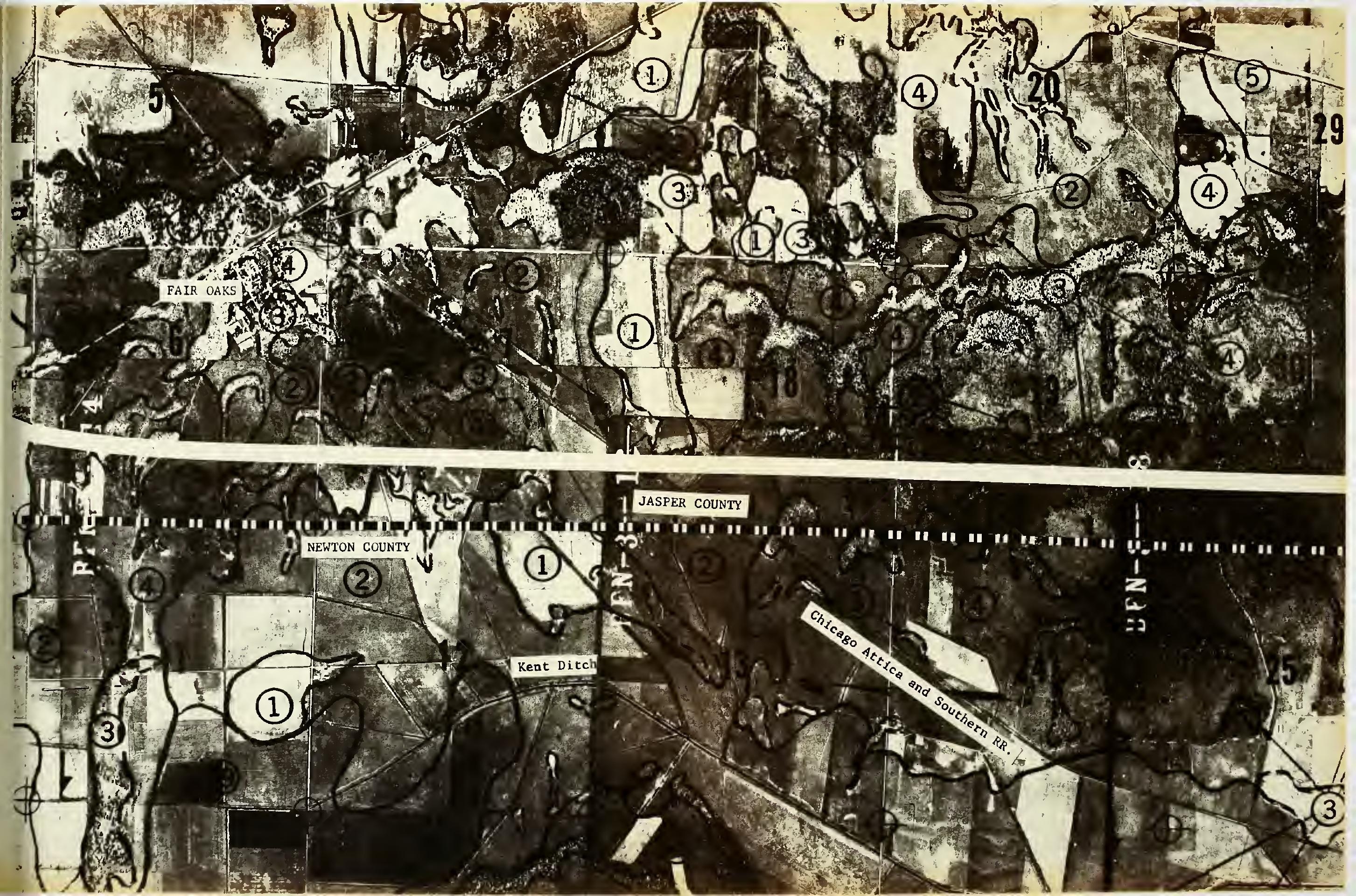
$1.12 \times 1-14$

Shas

2 (4.) 1 (1) $x+1,0,4)$ tit $\frac{14}{20}$

(x) +40 $x+1,4$

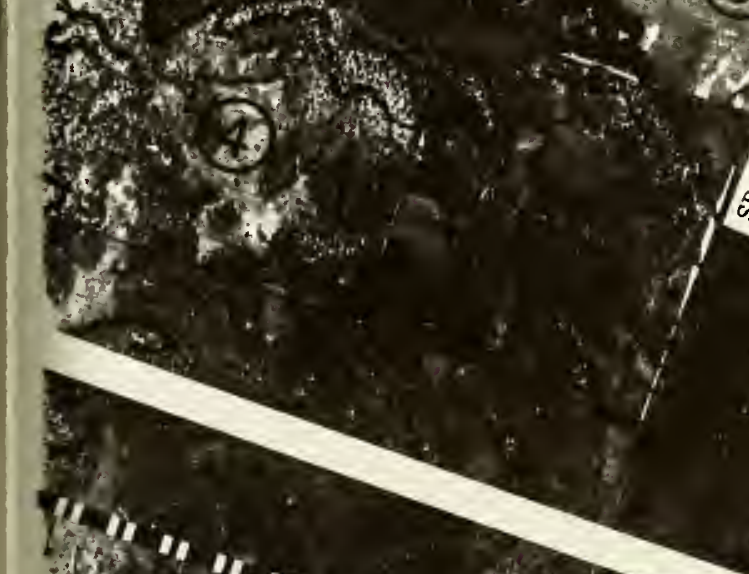

5 Tom

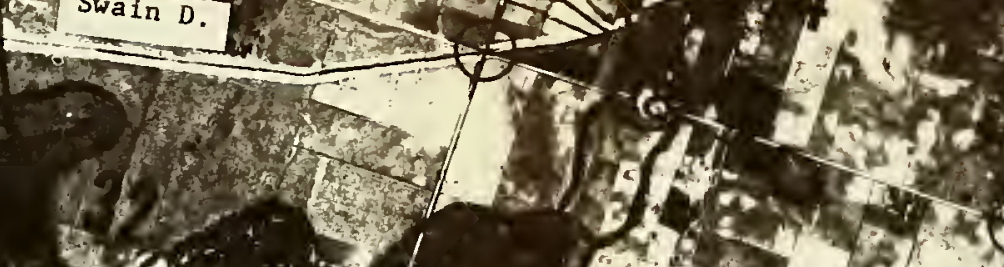

3

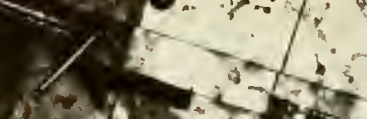

$\sqrt{1}$

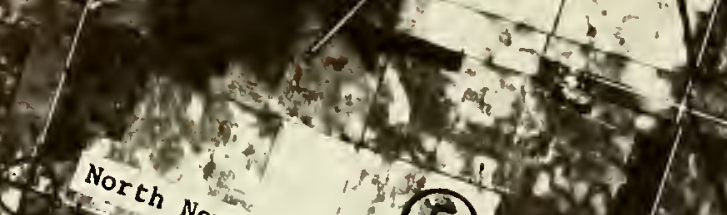

as 13. 31 .

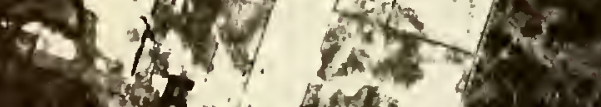

Ge $=0$

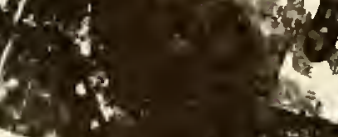

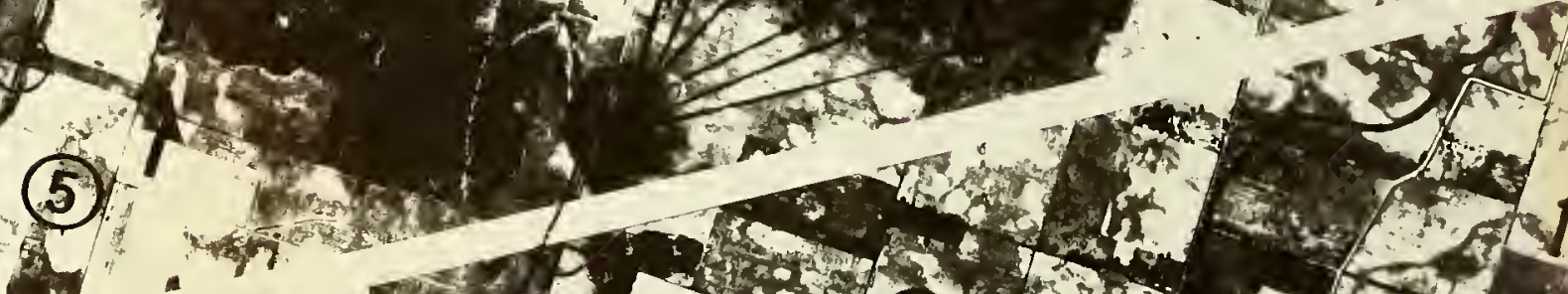

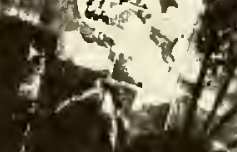

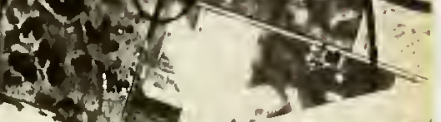

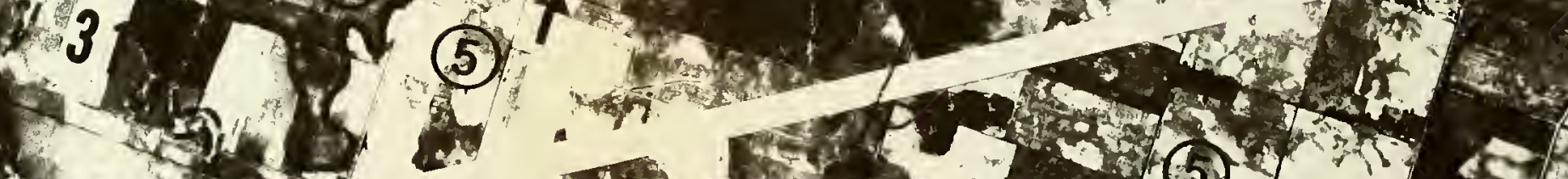

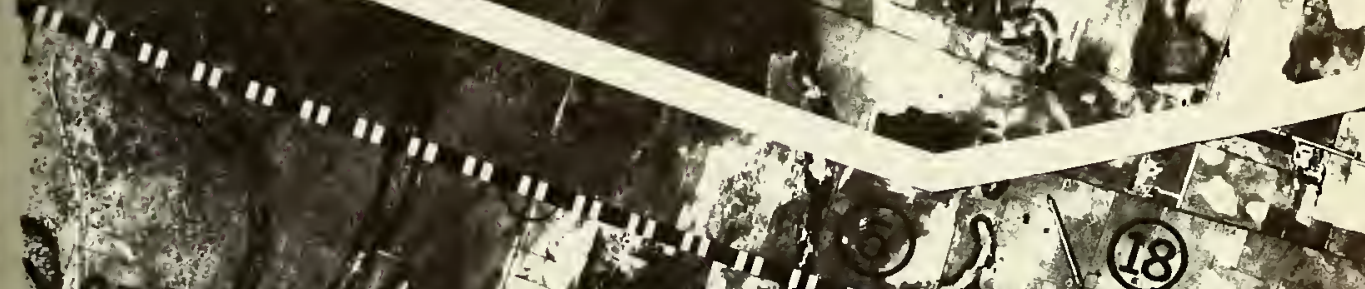

\section{(4)}

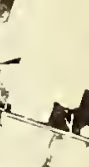

1919.

P.t. (1) $(5)$. $5 \%$ - 91

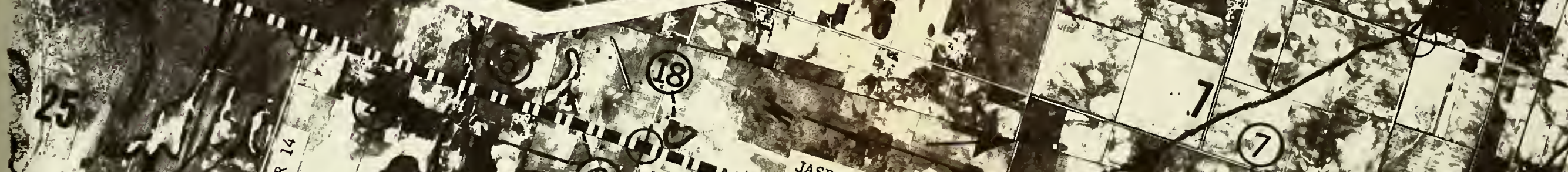

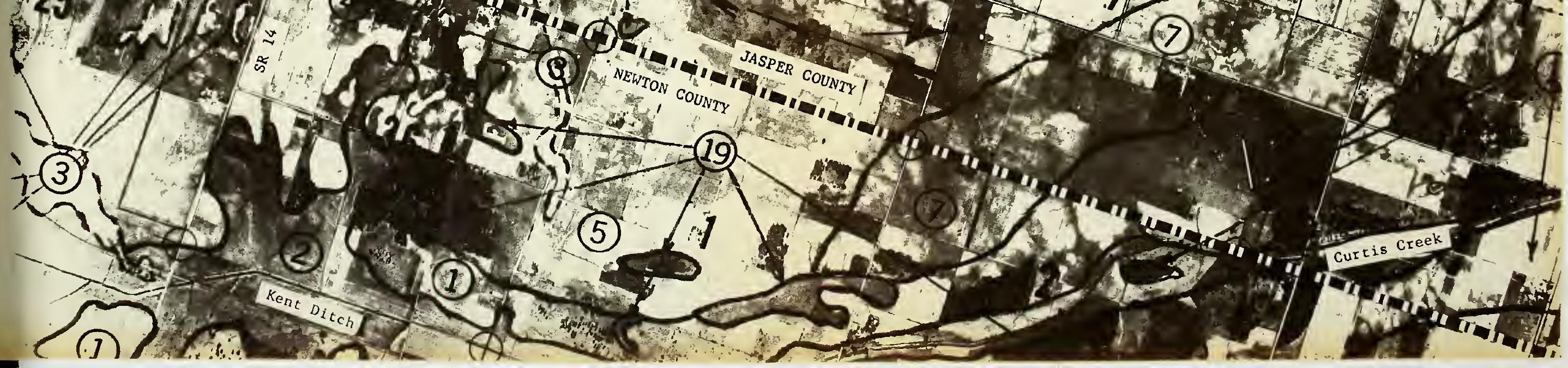




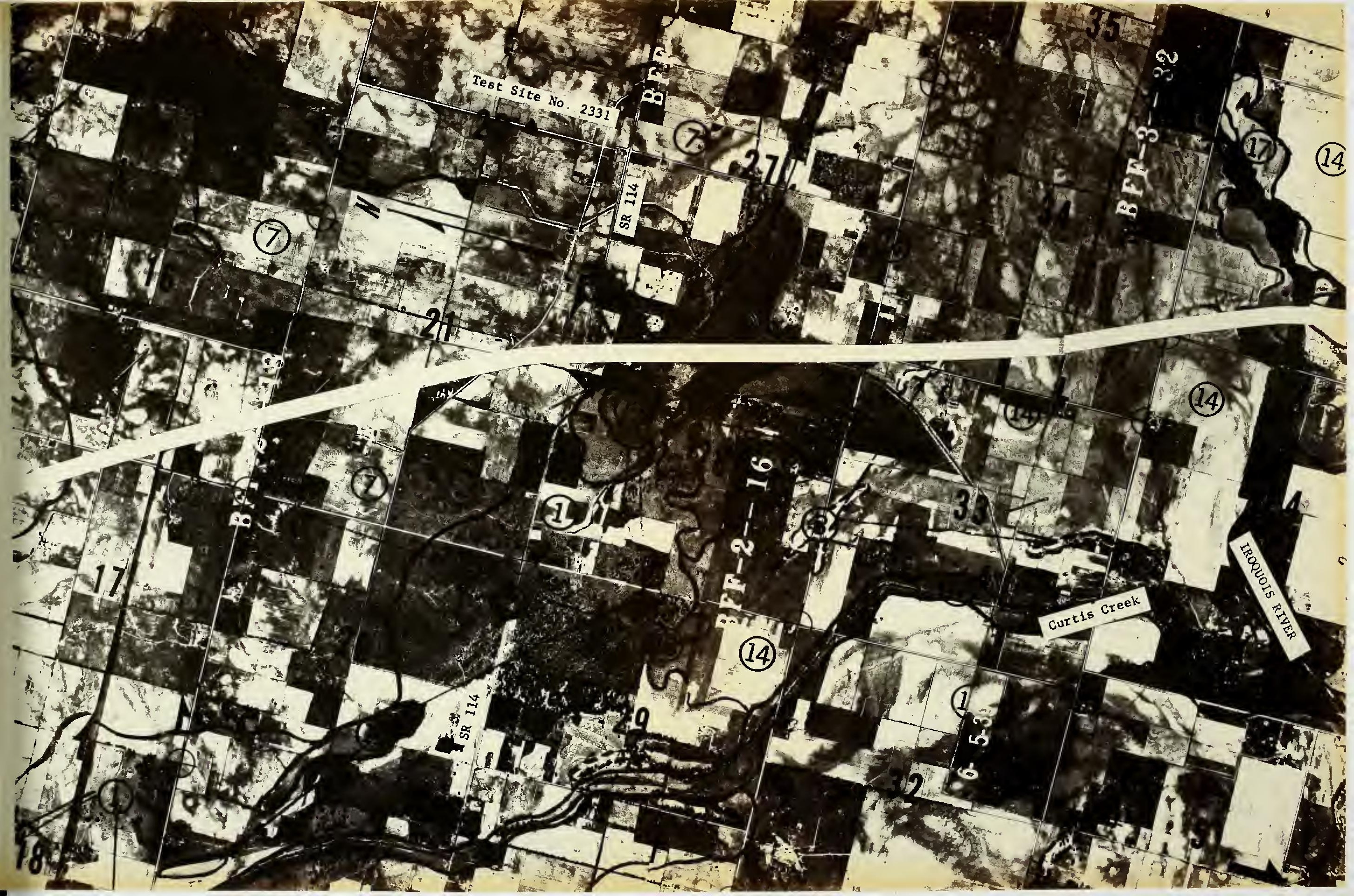




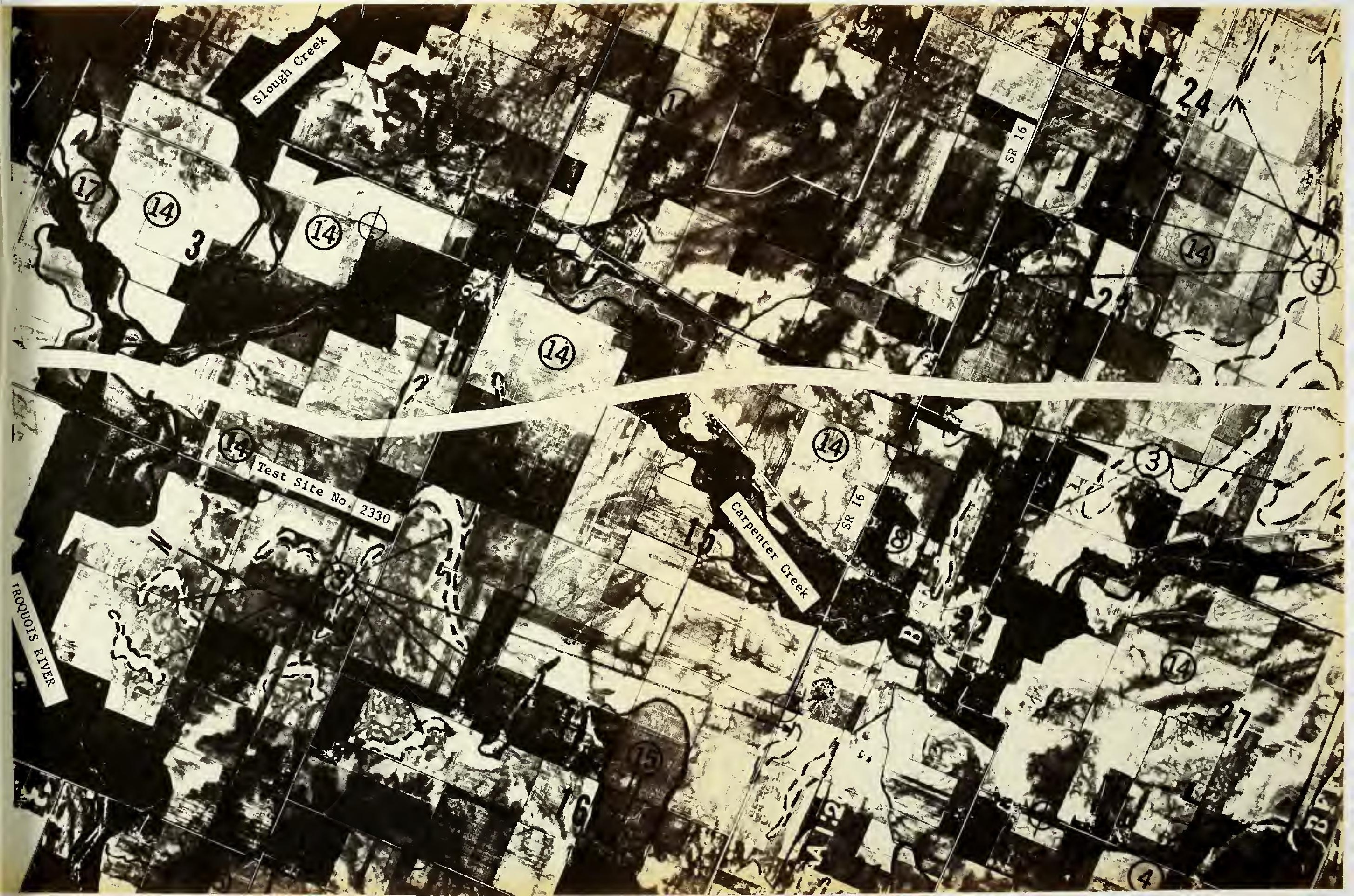




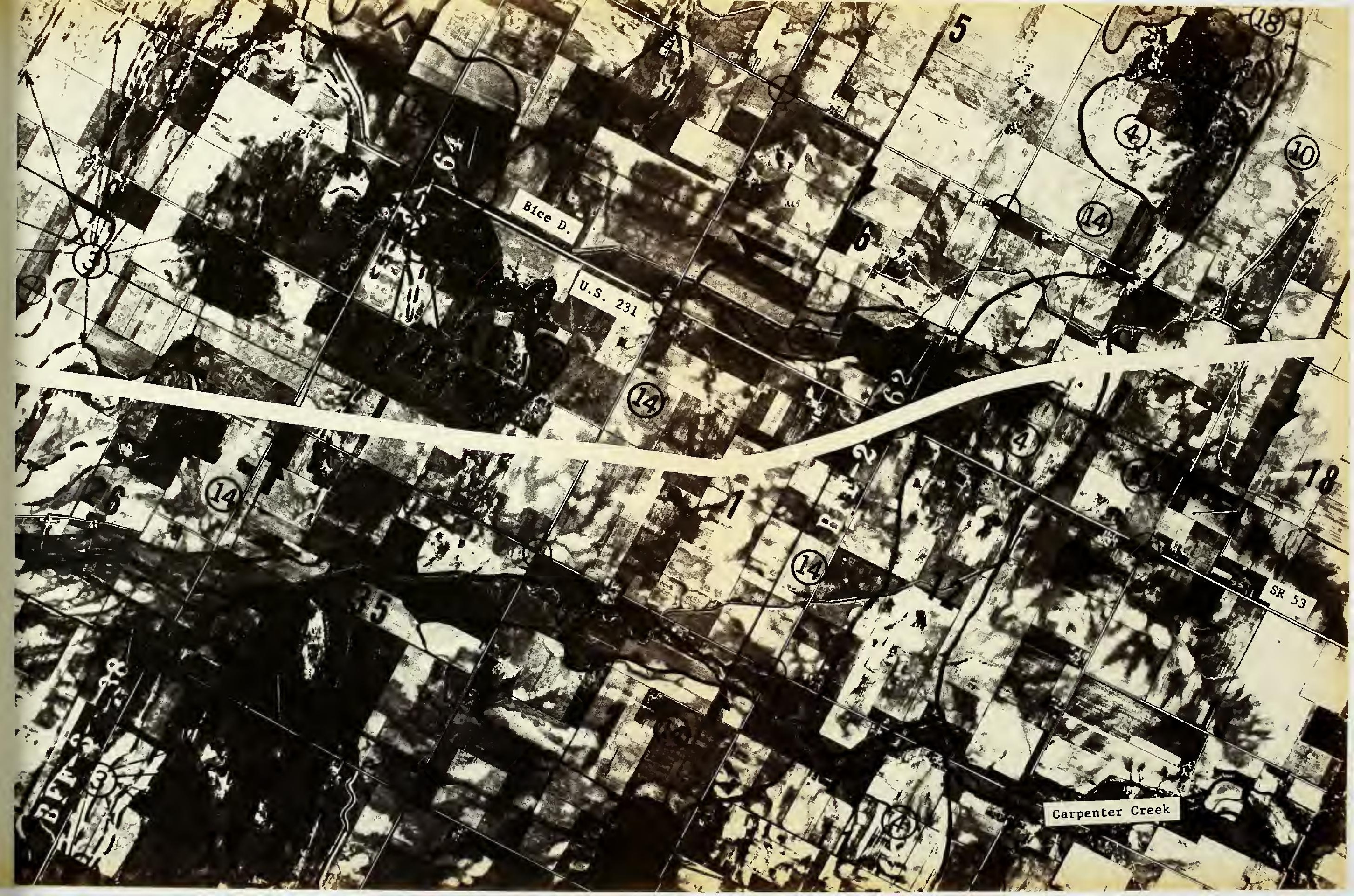




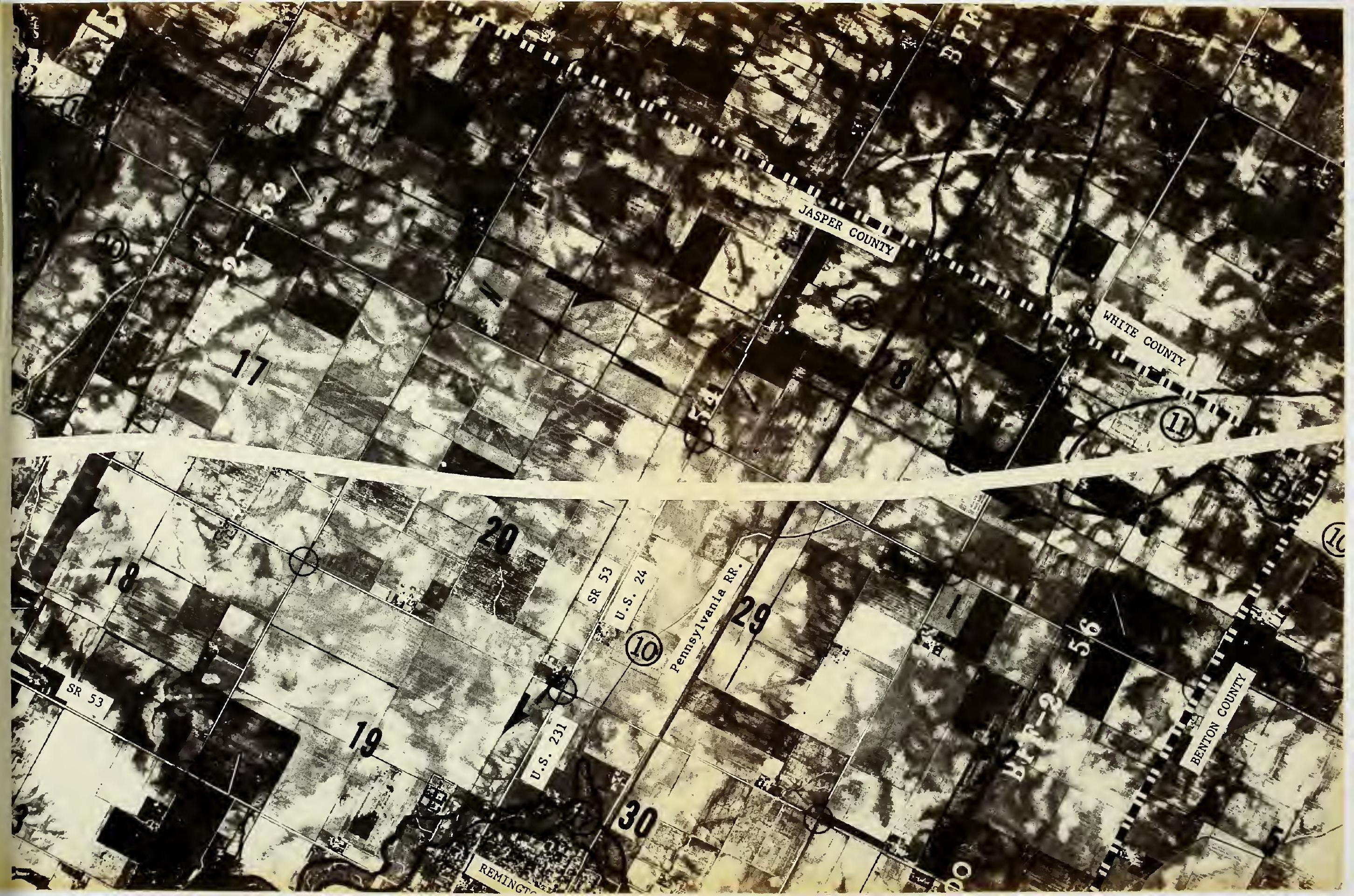




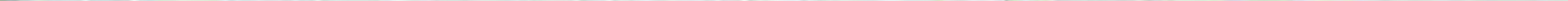




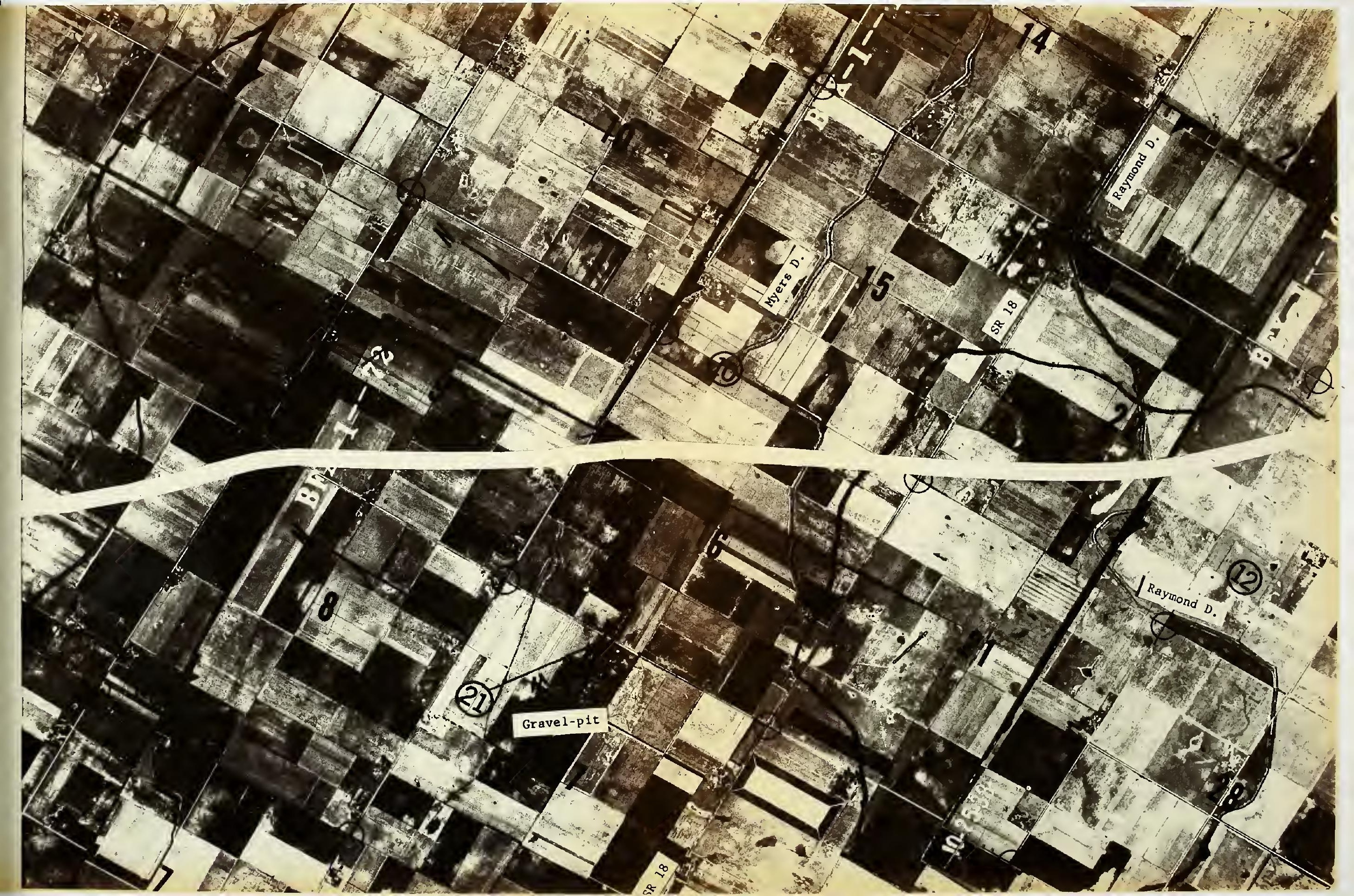




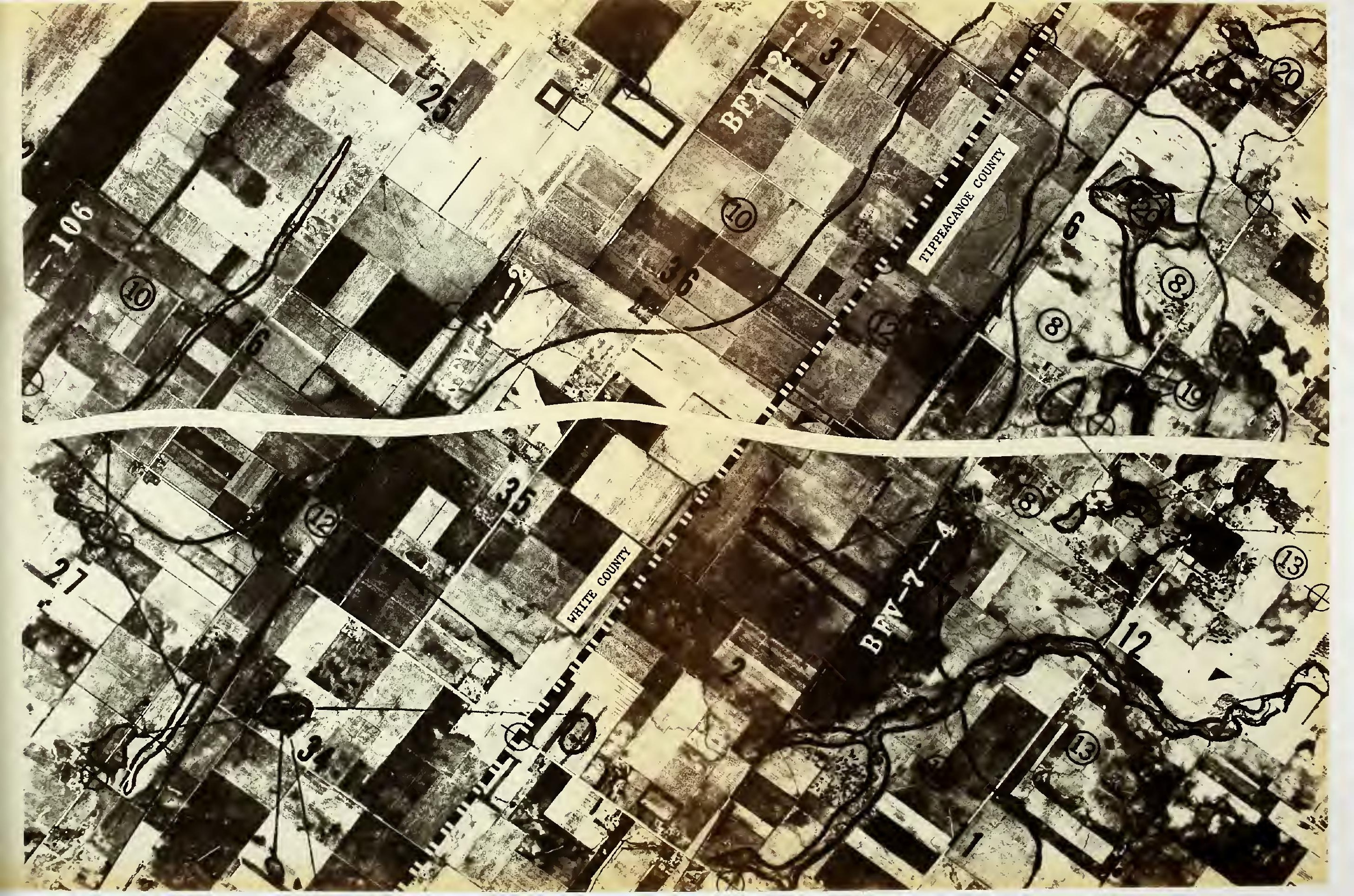




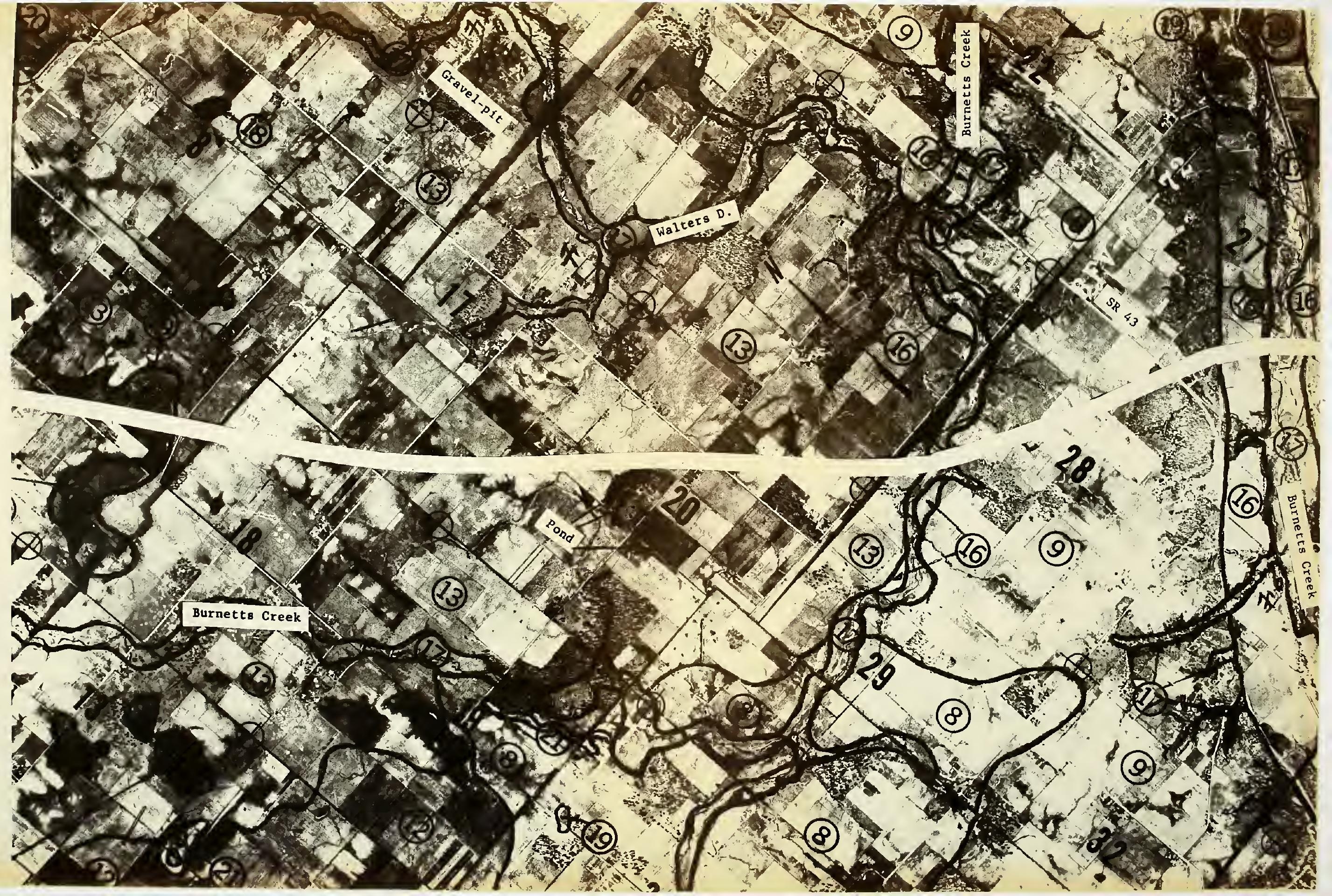




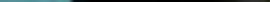

